\title{
Laboratory Diagnosis of Cutaneous and Visceral Leishmaniasis: Current and Future Methods
}

\author{
Juliana Quero Reimão ${ }^{1}\left(\mathbb{D}\right.$, Elizabeth Magiolo $\operatorname{Coser}^{2}{ }^{(\mathbb{C}}$, Monica Ran Lee ${ }^{1}(\mathbb{C}$ \\ and Adriano Cappellazzo Coelho ${ }^{2, * \mathbb{D}}$ \\ 1 Departamento de Morfologia e Patologia Básica, Faculdade de Medicina de Jundiaí, \\ Jundiaí 13202-550, Brazil; juliana_reimao@yahoo.com.br (J.Q.R.); m0nicalee@hotmail.com (M.R.L.) \\ 2 Departamento de Biologia Animal, Instituto de Biologia, Universidade Estadual de Campinas (UNICAMP), \\ Campinas 13083-862, Brazil; elizabethmcoser@hotmail.com \\ * Correspondence: accoelho@unicamp.br
}

Received: 26 September 2020; Accepted: 20 October 2020; Published: 22 October 2020

\begin{abstract}
Leishmaniasis is a neglected tropical disease with two main clinical forms: cutaneous and visceral leishmaniasis. Diagnosis of leishmaniasis is still a challenge, concerning the detection and correct identification of the species of the parasite, mainly in endemic areas where the absence of appropriate resources is still a problem. Most accessible methods for diagnosis, particularly in these areas, do not include the identification of each one of more than 20 species responsible for the disease. Here, we summarize the main methods used for the detection and identification of leishmaniasis that can be performed by demonstration of the parasite in biological samples from the patient through microscopic examination, by in vitro culture or animal inoculation; by molecular methods through the detection of parasite DNA; or by immunological methods through the detection of parasite antigens that may be present in urine or through the detection of specific antibodies against the parasite. Potential new methods that can be applied for laboratory diagnosis of leishmaniasis are also discussed.
\end{abstract}

Keywords: leishmaniasis; cutaneous leishmaniasis; visceral leishmaniasis; Leishmania; diagnosis

\section{Introduction}

Leishmaniasis is a parasitic disease caused by the parasite protozoan of the genus Leishmania that are transmitted to humans by the bite of a female sand fly vector. The parasite alternates between flagellated promastigotes in the insect vector and as intracellular amastigotes in the mammalian host. At least 20 species of parasite are responsible for visceral and cutaneous leishmaniasis in humans with clinical features of each form of the disease depending on the species of Leishmania and the immune response of the host [1,2]. This neglected tropical disease is found in all continents, except Oceania, including areas in Northeastern Africa, Southern Europe, Asia, and Latin America and affects almost one hundred countries [3]. The number of cases reported globally ranges from 0.2 to 0.4 million cases for visceral leishmaniasis (VL) and 0.7 to 1.2 million cases of cutaneous leishmaniasis (CL) per year, with an estimate of at least 20,000 deaths per year [3]. Only six countries suffer more than $90 \%$ of VL cases worldwide: India, Bangladesh, Sudan, South Sudan, Ethiopia, and Brazil, while CL is reported in a higher number of countries and almost $75 \%$ of cases occur in ten countries: Afghanistan, Algeria, Colombia, Brazil, Iran, Syria, Ethiopia, Sudan, Costa Rica, and Peru [3]. For CL, an increase in the incidence in the Middle East and Americas has been reported over recent years, particularly due to conflict and environmental factors [4].

Visceral leishmaniasis is the systemic form of the disease that affects mainly the liver, spleen, and bone marrow and may be lethal if not treated. It is caused by Leishmania (Leishmania) donovani in 
Northeastern Africa and Southeastern Asia and L. (L.) infantum in Southern Europe, Northeastern Africa, and Central and South America [2,5]. This clinical form of the disease has a zoonotic transmission in the case of L. (L.) infantum (from animal to vector to human) and an anthroponotic transmission (from human to vector to human) that is caused by L. (L.) donovani, although animal reservoirs, including dogs, have already been reported as hosts for this species [2,5,6]. Post-kala-azar dermal leishmaniasis (PKDL) is a complication of VL generally observed in post-treatment patients and immunosuppressed individuals infected by L. (L.) donovani and it is characterized by macular, papular, or nodular lesions on the skin [7]. Around 5-10\% of patients with VL develop this dermal manifestation that is mainly associated with incomplete treatment [8]. Most of the cases occur in Southeast Asia (India, Nepal, and Bangladesh) and East Africa (mainly Sudan) [7]. In addition to this, patients infected with VL may not develop clinical symptoms and may remain infected at a sub-clinical level, increasing the challenge of a correct diagnosis and appropriate treatment and consequently restricting the control of the disease in endemic areas [9].

The localized CL is characterized by a papule that develops at the site of the bite of the sand fly that enlarges to a nodule and then ulcerates [2]. In 10\% of cases, CL may progress in more severe manifestations: mucocutaneous leishmaniasis (ML), diffuse CL (DCL) and disseminated CL [2]. These different clinical manifestations of CL are caused by zoonotic species of Leishmania, with the exception of L. (L.) tropica that is also considered an anthroponotic species [10]. Mucocutaneous leishmaniasis is characterized by disfiguring and destructive lesions of the oronasopharyngeal mucosa, due to a strong immunopathological response and is caused by L. (Viannia) brazilensis and also L. (V.) guyanesis [2]; while DCL is caused by L. (L.) amazonensis, L. (L.) mexicana and L. (L.) aethiopica and is characterized by nodules spread across the body of the patient that do not ulcerate, in an immune status of absence of cellular response [2,11]. Finally, in the disseminated CL, the patient presents several pleomorphic lesions, with acneiform and papular aspect, distributed in noncontiguous areas of the body. Cases of disseminated CL have been correlated to L. (V.) braziliensis [12,13]. Moreover, similarly to VL, CL patients may not develop clinical symptoms either and the disease at a sub-clinical level may restrict the control of disease [9].

Leishmania/HIV co-infection cases have been reported for VL, PKDL, and CL patients, with an increasing number of cases worldwide due to the spread of the AIDS pandemic from urban to rural regions, being considered one of great challenges for leishmaniasis control [2,5,14-18]. In Europe, cases of VL/HIV co-infection have been noted in intravenous drug users through the sharing of needles [15]. Atypical clinical cases are recurrent in VL and CL patients co-infected with HIV, and more severe manifestations have also been reported [16,18]. In CL/HIV co-infected patients from Brazil, an extensive variety of lesions and ulcerations have been described [18], while in VL/HIV patients, parasites have been detected in organs that are not usually found in non-immunosuppressed patients, such as, for example, the gastrointestinal mucosa and respiratory tract [2,19]. HIV-infected patients have an increased risk of being infected by the parasite, and in the case of co-infection, the treatment may be compromised due to the role of CD4 ${ }^{+} \mathrm{T}$ cells in the clearance of intracellular amastigotes [20].

There is a limited number of drugs available for chemotherapy of leishmaniasis. Pentavalent antimonials, amphotericin B and pentamidine have been used against the parasite for several decades, while miltefosine and paromomycin have been approved for treatment more recently [21]. In general, the use of these drugs does not take into consideration the diversity of clinical forms of the disease, in part because the diagnosis methods for species discrimination are still limited in areas where more than one species is endemic.

The numerous clinical manifestations of the disease mean the diagnosis of current and previous cases of infection is still a challenge for the correct identification of the etiological agent of the disease. Lesions in CL, for example, may vary greatly in relation to the size, clinical appearance and period of evolution and spontaneous cure. Clinical findings in patients with CL due to L. (V.) braziliensis or L. (V.) guyanensis have already been associated with a particular aspect of skin lesions related to number, size, location and pattern of lymphatic involvement [22]. Patients infected by L. (V.) guyanensis 
had smaller and more numerous lesions, located in most of the cases above the waist, while in infections due to L. (V.) braziliensis, patients had fewer lesions that were located mainly on the lower limbs [22]. In addition, differential diagnosis is essential because other diseases may have clinical aspects similar to CL (e.g., leprosy, keloid, skin cancers, tuberculosis, cutaneous mycoses) and VL (e.g., Chagas disease, hepatosplenic schistosomiasis, amoebic liver abscess, disseminated histoplasmosis, mononucleosis, hepatitis, tuberculosis, malaria, sickle cell anemia, lymphoma, chronic myeloid leukemia, systemic lupus erythematosus, and liver cirrhosis, among others) [5,9,12]. In regions where the disease is endemic, the diagnostic tests available may be limited and depend more on the resources and infrastructure available than the accuracy of the employed method.

In this review, we describe the main methods available for detection and identification of CL and VL, and their current limitations and challenges. Current diagnostic methods include the parasitological, immunological and molecular methods. The broad spectrum of clinical manifestations in both main forms of disease makes differential diagnosis an essential goal to the current identification of the etiological agent of this spectrum of diseases. Challenge for the current laboratory methods of diagnosis are the detection of the etiological agent and the correct identification of the species responsible for the clinical form of the disease. Light-microscopic examination of tissue smears or sections (histopathology), in vitro culture, serologic testing, and molecular tests based on DNA detection and amplification are the most used options for leishmaniasis diagnosis [23] (Figure 1), as discussed below.

\section{Laboratorial Diagnosis of Leishmaniasis}

Sample acquisition: Biopsy, punch or scraping of lesion fragments for $\mathrm{CL}$; biopsy or aspiration from bone marrow, lymph nodes or spleen for VL; serum for antibody detection of both clinical forms.

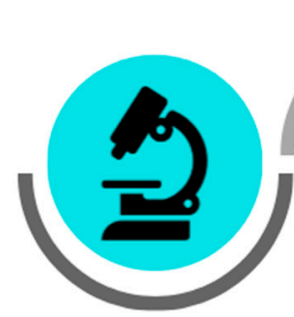

\section{Microscopy}

Based on visualization of amastigotes with Giemsa or hematoxylin and eosin stains upon microscopic

examination of tissue specimens.

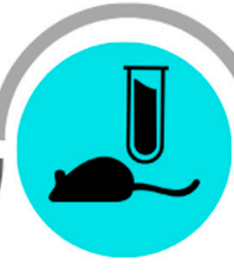

In vitro and in vivo isolation Promastigotes can be grown in a biphasic medium using a blood gar base. Inoculation of mice or hamsters can also result in parasite isolation.

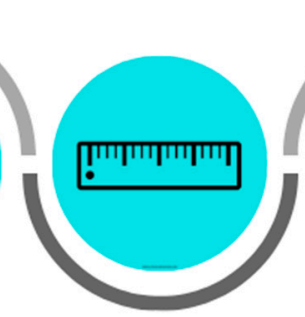

\section{In vivo immune} response Leishmania skin test measures delayed type hypersensitivity to antigens of the parasite. This is used for diagnosis of $\mathrm{CL}$.

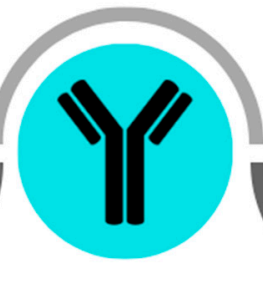

Antibody detection Mainly used for VL. The most commonly used techniques are ELISA, RDT and ICT (based on recombinant antigens, mainly rK39) for VL. For CL, ELISA and Western Blot are used.

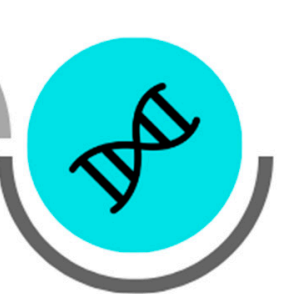

Molecular diagnosis Based mainly on DNA amplification by PCR. The most commonly used techniques for detection and typing are PCR-RFLP, realtime PCR, DNA sequencing and LAMP.

Figure 1. Illustrative image showing the most used tools and strategies for VL and CL laboratorial diagnosis.

\section{Parasitological Methods for Diagnosis of Leishmaniasis}

The parasitological methods are broadly practiced in leishmaniasis diagnosis, based on visualizing Leishmania amastigote forms in infected tissues [24]. While these techniques are highly specific for 
diagnosing leishmaniasis, they are insufficiently sensitive [25]. Moreover, these methods do not allow for discrimination between the different species of Leishmania. In CL, the sample is acquired through biopsy, punch, or scraping from mucosa or skin lesions. In skin lesions, the use of scrapings and cytology brushes is recommended instead of the more invasive biopsy [25]. The obtained sample stained with Giemsa proceeds to a histopathological exam, where amastigotes are identified through microscopical analysis. Moreover, the press-imprint-smear method is recommended since it is a quick, low cost, and relatively sensitive method. For the imprint, the biopsy sample is put on a glass slide, and another glass slide is used to cover the tissue fragment in the form of a sandwich. On a firm surface, the tissue fragment between both glass slides is squeezed. Pressure is applied to the middle of the slides causing the juice and tissue cells to spread out across both slides' surfaces that are in contact with the sample. The smears are then air dried, fixed in methanol, stained with Giemsa, and examined microscopically using a $100 \times$ oil immersion lens [26].

The parasitological exam is the current gold standard for diagnosis of $\mathrm{VL}$, in which the visualization of the amastigote form of the parasite in the biopsied material is the confirmatory diagnosis [27]. The biopsy should preferably be obtained from the bone marrow, since the procedure is more secure, or from the lymph nodes or spleen. Spleen biopsy must be performed in a hospital environment and under surgical conditions, as the spleen aspiration can be complicated by life-threatening hemorrhaging $(0.1 \%)$ amongst individuals associated with severe thrombocytopenia [28]. Sensitivity will vary according to the biopsied tissue, with spleen aspiration biopsy having the highest sensitivity, from $93 \%$ to $99 \%$ [27], followed by bone marrow aspiration, liver biopsy and lymph node aspiration. Furthermore, the obtained material can also be purposed for smears and examination after Giemsa staining.

\subsection{Microscopic Examination}

The microscopic exam is the most widely available test for the diagnosis of leishmaniasis, but it does not allow the identification of Leishmania species [23]. For CL, the direct examination of stained material removed from the lesion (obtained by biopsy, punch, scraping, smear or imprinting) using light microscopy, has a 50-70\% sensitivity for Leishmania species from Africa, Asia and Europe, and $15-30 \%$ for species from the Americas (Table 1) $[16,25,26,29,30]$. For samples from CL patients, a combination of different methods is recommended, given the limited sensitivity of these methods, particularly for samples of ML that have a low parasite load. Combination with PCR, for example, may increase sensitivity to more than $80 \%$ [31,32]. For VL, aspirates from the lymph nodes, bone marrow, or spleen are the main sources of samples for microscopic examination with relative variations in sensitivity; the aspirate of spleen being the sample with the highest sensitivity for microscopic analysis $[5,33,34]$. In the human host, only the amastigotes stage is seen through microscopic examination of tissue specimens, which can be visualized with both Giemsa and hematoxylin and eosin stains [23]. Leishmania amastigotes are intracellular round or oval bodies, about $2-4 \mu \mathrm{m}$ in diameter, with characteristic nuclei and kinetoplasts [35].

\subsection{In Vitro Cultivation of Leishmania}

An alternative to increasing sensitivity through direct examination is to use part of the biopsied material for inoculation in a culture medium, although this is rarely used in routine clinical practice (Table 1) [19]. Isolation followed by in vitro cultivation is useful for confirmation of Leishmania infection and for species identification by molecular methods (see below).

For isolation purposes, the culture medium should mimic the conditions of the vector insect to prompt viable amastigotes to differentiate promastigotes and reproduce [36]. Promastigotes can be grown in some media already established for cultivation of parasites at temperatures below $28^{\circ} \mathrm{C}$ (generally between $22{ }^{\circ} \mathrm{C}$ and $26^{\circ} \mathrm{C}$ ) [37]. The main media used for the cultivation of promastigotes are the biphasic medium, Nicolle's modification of Novy and MacNeal's medium (NNN), and Schneider's Drosophila medium supplemented with fetal bovine serum [37]. In these media, promastigotes are noted after a period of 7-21 and 2-7 days, after inoculation of amastigotes into NNN and Schneider's 
medium, respectively. Sensitivity of in vitro cultivation may also be dependent on the species of parasite. In skin aspirates, the sensitivity from samples of patients infected by L. $(V$.) braziliensis and L. (V.) guyanensis was of $47 \%$ and $91.2 \%$, respectively [22]. In vitro parasite growth in a culture medium takes several days and can eventually be contaminated with bacteria or fungi. Additionally, the results may vary depending on the parasite burden in the biopsy sample, the expertise of the laboratory technician and the culture media used [12,37].

More recently, a microculture technique has been developed as an alternative for parasite cultivation. This technique uses the scraping of a cutaneous lesion for cultivation in a capillary tube in sterile conditions [38]. This method is cost-effective and more sensitive than the standard cultivation, does not require the use of a needle and syringe, and can also be used for isolating parasites for drug susceptibility assays and typing. In the microculture technique, promastigotes can be noted after $2-3$ days and sensitivity and specificity were $94 \%$ and $100 \%$, respectively [38].

\subsection{Inoculation of Leishmania in Experimental Animals}

This method consists of the inoculation of parasites obtained from biological samples from patients into the footpad, nose, or tail base of mice (for $\mathrm{CL}$ ), or intravenous or intraperitoneal inoculation in mice or golden hamsters (for VL) (Table 1). Interestingly the development of the disease was faster in hamsters infected with $L$. (V.) guyanensis than in those infected with $L$. (V.) braziliensis, indicating that this diagnostic approach may be different depending on the species of parasite [22]. Inoculation in animals is a time-consuming procedure and require trained professionals to perform the procedure $[19,35]$. Inoculation of parasites in animals is restricted solely to research centers that contain animal facility to house stock, breed and perform experimental infection. This method is not considered a first diagnostic procedure, as several weeks are required for confirmation of the presence in the infected animals, but is an important complementary tool, especially in dubious cases [19]. 
Table 1. Summary of the main methods used for diagnosis of CL and VL.

\begin{tabular}{|c|c|c|c|c|c|}
\hline & Diagnostic Method & Clinical Form & Culture Required & Species Discrimination $^{1}$ & Reference(s) \\
\hline \multirow{5}{*}{ 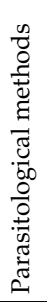 } & $\begin{array}{l}\text { Biopsy, punch, scraping, smear or imprinting } \\
\text { followed by microscopic examination }\end{array}$ & CL & No & No (only genus Leishmania) & {$[25,26,29,30]$} \\
\hline & $\begin{array}{l}\text { Bone marrow, lymph nodes or spleen aspirates or } \\
\text { liver biopsy followed by microscopic examination }\end{array}$ & $\mathrm{VL}$ & No & No (only genus Leishmania) & {$[33,34]$} \\
\hline & In vitro cultivation & $\mathrm{VL}, \mathrm{CL}$ & Yes & No (only genus Leishmania) & {$[37]$} \\
\hline & Inoculation in animals (mice or hamsters) & $\mathrm{VL}, \mathrm{CL}$ & No & No (only genus Leishmania) & {$[22,35]$} \\
\hline & Xenodiagnosis & VL & No & No (only genus Leishmania) & {$[39,40]$} \\
\hline \multirow{4}{*}{ 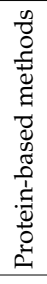 } & MLEE & $\mathrm{VL}, \mathrm{CL}$ & Yes & Yes (almost all currently identified species) & [41] \\
\hline & Monoclonal antibodies & $\mathrm{VL}, \mathrm{CL}$ & Yes & $\begin{array}{l}\text { Yes (almost all species endemic in the Americas } \\
\text { and also } L .(L .) \text { major, } L .(L .) \text { donovani and } \\
L .(L .) \text { tropica) }\end{array}$ & {$[42-45]$} \\
\hline & MALDI-TOF MS & $\mathrm{VL}, \mathrm{CL}$ & Yes & $\begin{array}{l}\text { Yes (all species endemic in the Americas, Europe, } \\
\text { Asia and Africa) }\end{array}$ & {$[46-48]$} \\
\hline & KAtex & $\mathrm{VL}$ & No & No (only genus Leishmania) & [49-51] \\
\hline \multirow{6}{*}{ 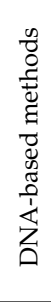 } & PCR-RFLP & $\mathrm{VL}, \mathrm{CL}$ & No & Yes (almost all species; depends on the target) & {$[9,52]$} \\
\hline & DNA sequencing & $\mathrm{VL}, \mathrm{CL}$ & No & Yes (almost all species; depends on the target) & {$[9,52]$} \\
\hline & Real-time PCR & $\mathrm{VL}, \mathrm{CL}$ & No & Yes (most species) & {$[53,54]$} \\
\hline & PCR-HRM & $\mathrm{VL}, \mathrm{CL}$ & No & $\begin{array}{l}\text { Yes (almost all species endemic in the Americas, } \\
\text { Europe, Asia and Africa) }\end{array}$ & [55-59] \\
\hline & MLST & $\mathrm{VL}, \mathrm{CL}$ & No & Yes (all species) & {$[60-63]$} \\
\hline & LAMP & $\mathrm{VL}, \mathrm{CL}$ & No & Yes (limited to certain species) & [64-67] \\
\hline \multirow{8}{*}{ 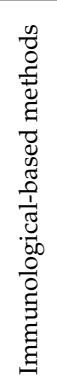 } & Leishmania skin test & $\begin{array}{l}\text { CL (negative for } \\
\text { DCL) }\end{array}$ & No & No (only genus Leishmania) & [16] \\
\hline & ELISA (rK39) & VL & No & No (only genus Leishmania) & [68-73] \\
\hline & ELISA (other recombinant antigens) & $\mathrm{VL}, \mathrm{CL}$ & No & No (only genus Leishmania) & [74-85] \\
\hline & IFAT & $\mathrm{VL}, \mathrm{CL}$ & No & No (only genus Leishmania) & [71,86-89] \\
\hline & DAT & $\mathrm{VL}$ & No & No (only genus Leishmania) & {$[50,71,86,87,90,91$} \\
\hline & ICT (rK39) & $\mathrm{VL}$ & No & No (only genus Leishmania) & {$[50,70,86,90,92]$} \\
\hline & Dipstick test [L. (L.) donovani promastigote antigens] & $\mathrm{VL}$ & No & No (only genus Leishmania) & {$[93,94]$} \\
\hline & Western blot & $\mathrm{VL}, \mathrm{CL}$ & No & No (only genus Leishmania) & [95-98] \\
\hline
\end{tabular}

${ }^{1}$ Check in the text and references for details of species evaluated in the respective methods. 


\subsection{Xenodiagnosis}

Xenodiagnosis is a method that uses the insect vector of a pathogen as a culture medium for the detection of infection in a mammalian host/patient [40]. In Chagas disease, xenodiagnosis is a classical method that documents the presence of Trypanosoma cruzi by exposing possibly infected blood of the patient to nymphs of the triatome bugs and then examining the vector for the presence of the parasite it may have ingested [99]. This method can be performed in two distinct ways: direct or indirect xenodiagnosis. In direct xenodiagnosis, an uninfected hematophagous insect feeds on a suspected individual while in the indirect method, the insect feeds on heparinized blood through a feeder membrane (e.g., chicken skin) [40]. The latter method avoids the risks of hypersensitivity to insect bites and transmission of other infectious agents. Xenodiagnosis was adapted for experimental leishmaniasis using mice infected with $L$. (L.) donovani as a model [100] and was recently applied for diagnosis on VL and PKDL patients, by the direct and indirect procedures that were infectious to the sand fly Phlebotomus argentipes (Table 1) [39]. Direct xenodiagnosis was significantly more sensitive than the indirect xenodiagnosis and parameters associated with positive xenodiagnosis were nodular lesions, parasite burden and positive microscopy skin [39]. It would be interesting to investigate the potential for detection of this method in infected, cured, and asymptomatic patients, particularly those with CL.

As other parasitological methods, this method does not discriminate Leishmania species and is time-consuming (requiring 2-5 days to get final results). Additionally, it requires a well-established sand fly rearing laboratory and a trained entomologist for dissection of the sand flies for microscopic examination of Leishmania infection [40,101].

\section{Molecular Methods for Diagnosis of Leishmaniasis}

Several molecular methods have already been evaluated for diagnosis of leishmaniasis. PCR-based assays are the basis for Leishmania detection and typing (Table 1). They have been considered the main method for molecular diagnosis of leishmaniasis. PCR-based assays are highly recommended for species typing, particularly for species responsible for CL that may be caused by different species of the parasite. In Brazil, for example, at least seven species may cause CL. The advantage of using PCR-based methods are, in general, their feasibility, safety, and reliability for application in a routine laboratory [102]. As an alternative for species typing, there is multilocus enzyme electrophoresis (MLEE) based on the profile of proteins of a specific species (see below). Recently, mass spectrometry was also proposed as an alternative for species identification of Leishmania [47].

\subsection{Multilocus Enzyme Electrophoresis (MLEE)}

This method is completely dependent on isolation of the parasite followed by its cultivation and is based on the profile of a set of proteins in a $\mathrm{pH}$-dependent gel electrophoresis. The classification of each species is determined by the combination of these proteins (described as zymodeme) (Table 1) [41]. MLEE is considered to be the gold standard for Leishmania typing by the World Health Organization (WHO) and it is maybe the only method available that is able to discriminate almost all the species responsible for human leishmaniasis [52]. MLEE also requires a high level of technical expertise of the professionals and is extremely time-consuming. Based on the reference strains of the parasite, the MLEE method covers variations in the genus Leishmania, but its use is limited to a restricted number of laboratories worldwide.

\subsection{Monoclonal Antibodies}

The use of monoclonal antibodies was also established for identification of Leishmania species, and similarly to MLEE, requires isolation followed by cultivation of parasites as promastigotes. The most extensive study, for species discrimination, reported the generation of monoclonal antibodies against almost all species endemic in Americas of both subgenera (Table 1) [42]. Monoclonal antibodies specific 
to species endemic in Europe, Asia, and Africa were also generated and are available for L. (L.) major, L. (L.) donovani, and L. (L.) tropica [43-45]. This method is rarely applied in the clinical context, since the procedure is time-consuming, and requires highly trained professionals and standardization. Moreover, its use is restricted to parasites obtained from clinical samples.

\subsection{Mass Spectrometry (MS)}

Matrix-assisted laser desorption ionization time-of-flight (MALDI-TOF) MS has already been proposed as an alternative for identification of prokaryotic and eukaryotic unicellular organisms [103,104]. MALDI-TOF MS was also implemented for species identification of the genus Leishmania (Table 1) [46-48]. This approach was applied using cultivated Leishmania promastigotes from a 56-reference database, that was then used for typing a panel of 69 isolates obtained from patients, where 66 were correctly identified [46]. This approach was later improved through the construction of a reference mass-spectral library for Leishmania identification using 33 species of 10 complexes that were then tested with an independent panel of 268 samples from different sources [47]. Among isolates, only one was misidentified at the complex level (typed as L. (V.) guyanensis instead of L. (V.) braziliensis), and the other 30 misidentifications were limited to the following complexes: L. (V.) braziliensis (L. (V.) braziliensis/ L. (V.) peruviana), L. (V.) guyanensis (L. (V.) guyanensis/L. (V.) shawi/L. (V.) panamensis), and L. (L.) donovani (L. (L.) donovani/L. (L.) infantum/L. (L.) archibaldi) [47]. This method proved to be a potential tool for species typing, and was faster compared to other molecular methods (if considered that the parasite was already isolated). Unfortunately, there is the need of a fully-equipped laboratory containing costly equipment and professionals trained in the performance of MALDI-TOF MS analyses. Finally, similar to MLEE and the use of monoclonal antibodies for typing, MALDI-TOF MS also requires isolation and cultivation of the parasite for species identification.

\subsection{PCR-Based Methods}

Several PCR-based methods have a level of sensitivity sufficient for the detection and typing of Leishmania species. The main advantage of PCR-based approaches is that they do not require parasite cultivation and may be directly applied to clinical samples. PCR-based approaches are based on coding or non-coding regions of the nuclear and mitochondrial genomes of the parasite. The PCR product consists of a specific amplification of the target DNA evaluated on a conventional agarose gel followed by downstream analysis, such as through the use of restriction endonucleases, hybridization, or DNA sequencing [52,105], or by detection and analysis of fluorescent signals during amplification in a real-time PCR apparatus (Table 1). The signal is generated mainly by the use of intercalating fluorescent dyes (e.g., SYBR Green) or fluorescent probes (e.g., TaqMan ${ }^{\circledR}$ ) $[106,107]$ (see below). Beyond detection and typing of the parasites, a quantitative PCR may also be useful for monitoring clinical cure and follow-up of patients [108].

Alternatively, a specific PCR product targeting single or multiple species is also available, and, in general, they are able to identify subgenera and/or a group of species [52]. More recently, loop-mediated isothermal amplification (LAMP) has also been validated as an alternative method for diagnosis (Table 1) [66,109]. Finally, for all these methods, standardization and optimization are required for use in hospitals and reference centers. To achieve reliable results, a standardized genomic DNA extraction protocol, internal controls for PCR reaction and genomic DNA of reference strains as control are all highly recommended. Evaluation by an external quality control program is also recommended $[16,110]$.

\subsubsection{PCR-RFLP (Restriction Fragment Length Polymorphism)}

This approach is based on the pattern of DNA fragments after digestion with one or some restriction enzymes and then evaluated in gel electrophoresis. The technique is relatively simple and can be performed in a laboratory with a PCR machine. The main targets used for this method 
are rDNA locus (ITS1 and ITS2), the heat shock protein 70 (hsp70) gene, miniexon for nuclear DNA, and minicircles for kinetoplast DNA (kDNA) (Table 1) [9,52].

The rDNA locus in Leishmania has around 10-20 repeated copies in tandem in a single chromosome of the parasite [111]. Each unit of repetition of around $12.5 \mathrm{~kb}$ contains the ribosomal genes and spacers. Using rDNA as a target, ITS1 and 5.8S were applied for evaluation of PCR-RFLP using the HaeIII restriction enzyme for species discrimination. This method was evaluated in clinical samples and was useful for discrimination of the subgenus Leishmania [112]. Although divergent for discrimination of species of the subgenus Viannia by DNA sequencing, this PCR-RFLP protocol is unable to discriminate these species. This is possible when using ITS1, 5.8S, and ITS2, a region termed as IRT (intergenic region typing), for species discrimination of this subgenus, although several restriction enzymes need to be used [113]. Finally, due to the high level of conservation, 18S (or SSU) is not useful for species discrimination [114].

The $h s p 70$ gene has been extensively studied and validated as a potential target for species discrimination by the PCR-RFLP approach. This gene of 5-10 copies per haploid genome was initially evaluated as a potential marker for discrimination of species of the subgenus Viannia [115]. Further studies used other restriction enzymes and amplified fragments targeting this gene that were also described as useful for species discrimination [116-118]. On the other hand, this target should be used with care, particularly for some species of subgenus Viannia that may have the same profile of restriction with the HaeIII enzyme (L. $(V$.$) guyanensis and L$. $(V$.$) lindenbergi), whilst different strains and$ isolates of the same species may have different profiles with the same restriction enzyme, leading to misidentification [119]. Alternatively, Leishmania typing using the hsp70 gene may be solved by DNA sequencing [119] or HRM [57] (see below).

The miniexon gene is a multicopy gene distributed in tandem in Leishmania (100-200 copies), making this locus a potential target for parasite detection directly in clinical specimens [120]. Both exon and intron sequences are conserved and only the intergenic region of miniexon genes may be an alternative for discrimination of some species of Leishmania by PCR amplification [121,122]. The employment of a RFLP approach to this target increases the number of species that can be identified $[120,123]$. This method was not evaluated in $L$. (V.) lainsoni and L. (V.) lindenbergi and cannot discriminate $L .(V$.$) guyanensis/L. (V.) panamensis and L. (V$.$) braziliensis/L. (V$.$) peruviana [120,123]$. Later, it was demonstrated that sequencing of the amplified fragment is more informative than a restriction profile that needs up to five restriction enzymes for species discrimination [124].

Coding genes of antigens, mainly the metalloprotease glycoprotein 63 (GP63) and cysteine proteinase $\mathrm{B}(\mathrm{CPB})$, were also validated for Leishmania typing [52]. Both are multicopy genes present in tandem in the Leishmania genome, offering sensitivity for application in clinical samples without the need for isolation [52]. Although validated in the main endemic species responsible for the clinical forms worldwide, there is still no study using these targets as a universal protocol to describe Leishmania species by PCR-RFLP $[125,126]$. Interestingly, a combination of multiple targets (gp63, hsp70, cpb, and $h 2 b$ (histone H2B)) for typing using a PCR-RFLP analysis proved to be a robust method for the typing of strains and isolates of Leishmania endemic in the Americas [127].

Mitochondrial DNA of Leishmania consists of approximately 10,000 copies of minicircles of $0.5-2 \mathrm{~kb}$ and around $20-40$ copies of maxicircles of approximately $20-40 \mathrm{~kb}$, termed as kinetoplast DNA (kDNA) [128]. These two classes of molecules contain genes that encode mitochondrial genes (in maxicircles) and small RNAs, termed guide RNAs (in minicircles). The elevated number of copies of both classes of these circular DNAs allows their use as target for detection of the parasite directly from clinical sample. Polymorphisms in size of minicircles were investigated for identification and discrimination of Leishmania species. Although some differences occur in the size of the variable region of minicircles in Leishmania species, some species have a similar size, restricting their use for species discrimination of both subgenera $[129,130]$. Moreover, these studies were performed essentially in reference strains and variability in minicircles may be found in clinical isolates of the same species, hindering its use for species discrimination $[52,54]$. 


\subsubsection{DNA Sequencing}

This is based on technology described by Sanger et al., [131] that uses the incorporation of chain-terminating dideoxynucleotides for the determination of the nucleotide sequence of a determined fragment of DNA, being highly useful for identification of Leishmania species. In addition, DNA sequencing may be useful for phylogenetic studies [9]. By means of this method, typing of Leishmania species may be performed by analysis of single nucleotide polymorphisms (SNPs) or by comparison of the sample's sequence with reference sequences of Leishmania spp. in a dendrogram [52]. DNA sequencing of PCR-amplified products has been applied to several targets of the genome of the parasite for species identification. It has been described as useful for species discrimination using several nuclear and kDNA targets. The main targets used for DNA sequencing are rDNA (18S, ITS1 and ITS2), $h s p 70$, miniexon, 7SL RNA, genes encoding metabolism enzymes for nuclear DNA and cytochrome B and minicircles for kDNA (Table 1) [9,52].

In the rDNA locus, the main regions useful for detection and typing species of parasite are 18S, ITS1 and ITS2. In the case of 18S, the limitation is its high level of conservation, preventing its capacity for species discrimination; although it may be useful for discrimination of genus Leishmania from other trypanosomatids and human genomic DNA [114,132]. On the other hand, ITS regions are highly variable among species of both subgenera, allowing the correct typing of Leishmania species by DNA sequencing $[133,134]$.

The $h s p 70$ gene sequence has also been used for species discrimination, whilst it can also be used for studies involving taxonomy and phylogeny $[52,134,135]$. SNPs in the coding sequence of this gene are enough for discrimination of Leishmania species of both subgenera, including species less prevalent in endemic areas of South America, such as L. (V.) naiffi and L. (V.) lindenbergi [119,134-136].

The miniexon gene is conserved and is not useful for species discrimination by DNA sequencing [137]. On the other hand, the non-transcribed spacer is highly variable in sequence and size, allowing discrimination of the Leishmania subgenus and most species of the subgenus Viannia (L. (V.) lainsoni and L. (V) lindenbergi were not evaluated) [134]. Another alternative is the gene encoding 7SL RNA that is present in several copies in the genome of the parasite. It has a divergent domain making it a potential target for detection and discrimination of Leishmania species [138,139]. Some studies evaluated the 7SL RNA gene for species discrimination and although most species can be discriminated, it is not possible to discriminate $L$. (L.) donovani/L. (L.) infantum, L. (V.) naiffi/L. (V.) braziliensis, and L. (L.) mexicana/L. (L.) pifanoi by sequencing $[134,139]$. Several other genes encoding metabolism enzymes may also be used simultaneously for species discrimination (see below in Section 3.4.3. Multilocus Sequence Typing). These genes have not yet been evaluated individually and the potential of these genes for species discrimination is still unknown. These genes are single copy, limiting their direct detection in clinical samples.

For the kDNA, the only target already proven to be useful for species discrimination is the cytochrome B gene. Nucleotide sequence analysis revealed limitation for discrimination of $L$. (L.) donovani/L. (L.) infantum and L. (V.) braziliensis/L. (V.) peruviana [52]. Minicircles, another component of kDNA, may be useful for parasite detection due to the high number of copies, however, their variability within one strain/isolate prevents their use for species discrimination by DNA sequencing $[54,121,140]$.

\subsubsection{Multilocus Sequence Typing (MLST)}

This method uses the PCR method followed by DNA sequencing of some housekeeping genes (between 4 and 6) that are evaluated simultaneously. MLST increases the capacity of discrimination among different clinical samples, mainly in endemic regions. The main genes used in MLST analyses are aspartate aminotransferase (ASAT), isocitrate dehydrogenase (ICD), malic enzyme, mannose phosphate isomerase (MPI), 6-phosphogluconate dehydrogenase (6PGD), glucose-6-phosphate dehydrogenase (G6PD), glucose-6-phosphate isomerase (GPI), fumarate hydratase (FH), nucleoside hydrolase 1 (NH1), and nucleoside hydrolase 2 (NH2) [60-63]. Other genes that can be useful for Leishmania species typing 
by MLST are hsp70, miniexon, rDNA ITS1, and the 7SL RNA gene [134]. In general, this method has lower sensitivity than a single PCR method and requires optimization before implementation [102].

\subsubsection{Whole-Genome Sequencing (WGS)}

Beyond studies on genomics and transcriptomics, for example, WGS by next generation technologies may also emerge as an alternative for identification and discrimination of different species of pathogens [141-143]. WGS was first applied for diagnosis in a sample of bone marrow aspirate from an immunosuppressed 61-year-old patient that confirmed an infection by L. (L.) infantum, probably acquired during a trip to Southern Italy [144]. This technology may also be useful for molecular surveillance of the disease, providing answers to key epidemiological questions of importance to public health, such as, for example: characterization of transmission cycles, detection of variants of the parasite with possible new clinical features, identification of genetic markers of clinical and epidemiological relevance, such as genes related to drug resistance and virulence, among others [145]. Although the cost is still the main limitation for this technology, WGS was also applied for the analysis of genomes of parasites from clinical samples of patients with VL due to $L$. (L.) donovani [146]. The main advantage of this technology is that it does not require parasite cultivation, thereby avoiding possible biological biases in the analyses. Variations in the genome and in the number of chromosome copies were found when these samples were compared to the genomic DNA of promastigotes cultivated in vitro [146].

\subsubsection{Real-Time PCR}

Real-time PCR measures the amount of DNA generated by monitoring the amplification of a specific target during each PCR cycle. It has also been described as an alternative for diagnosis of leishmaniasis. Several methods have been implemented for detection, quantification of parasite burden and species typing, using different targets and protocols (reviewed by [107]). It has advantages including higher sensitivity, with a simpler standardization procedure, compared to standard PCR protocols. Moreover, there is no need for PCR product manipulation, since it is unnecessary to perform gel electrophoresis. As other PCR-based methods, real-time PCR protocols have been established using similar targets, such as kDNA, rDNA locus, hsp70, and other protein coding genes of the parasite (Table 1). Most of these protocols were performed using SYBR Green or TaqMan, while others were performed with MeltDoctor and LightCycler probes [107].

In patients with PKDL, real-time PCR was evaluated as a method for diagnosis and showed more than $90 \%$ sensitivity, while the sensitivity of microscopy was only $50.6 \%$ [147]. In an endemic area in Brazil, real-time PCR using SYBR Green or TaqMan was evaluated for diagnosis of CL and ML using two pair of primers targeting the kDNA of L. (Viannia) species, with $100 \%$ specificity and variation in sensitivity depending on the sample (biopsy or swab) and method used (ranging from $73.61 \%$ to $87.88 \%$ ) [148]. In CL, specificity and sensitivity of detection may be affected by the method used for sample collection and must be selected appropriately [149]. For evaluation of parasite load by real-time PCR, the sort of lesion sample harvesting may also affect the quantification, with a higher detection in cytology brushes and scrapings samples when compared to biopsies, for example [25,150]. Real-time PCR applied to the investigation of parasite load in patients exposed to the treatment has already been evaluated in some studies. This can be useful for monitoring the efficacy of the treatment and identifying potential relapses, for example. In patients co-infected with HIV and VL, a significant decrease in the parasite burden was found in patients treated with amphotericin $B$, three months after the end of the treatment [151]. The parasite load could be used to predict cure and relapses with a sensitivity of $100 \%$ and specificity higher than $90 \%$ [151]. Similarly, monitoring of VL treatment through real-time PCR was also demonstrated in other studies using blood samples from patients. A consistent association between positive samples and relapsed patients was found, while patients that evolved to a clinical cure showed negative results in relation to the presence of the parasite DNA $[152,153]$. On the other hand, the application of real-time PCR for parasite loading in CL infections is more challenging 
throughout the treatment of the patients. First, in general, patients with ML had a lower parasite burden than localized CL infections, which can interfere with the sensitivity of the assay, as described in a SYBR green-based qPCR assay targeting kDNA to simultaneously detect and quantify L. (Viannia) species [154]. Depending on the causative species, the parasite loading may also be significantly different, with the highest burden in patients with severe ML disease [155]. Moreover, in patients that did not respond to treatment, a correlation with undetectable parasite loading was found, suggesting that the persistence of the parasite may be due to a limited access to the drugs or localization of the parasites in other tissues/locations not related with the primary infection; in this case the mucosal lesion [155]. Multiple infection genotypes associated with the same disease are also a challenge, since quiescent parasites and/or less sensitivity to the drugs, for example, may persist and consequently affect the determination of the parasite burden [156]. Real-time PCR was used for detection of CL in asymptomatic and subclinical infections using 7SL RNA as the target and for the determination of parasite viability [157]. The results demonstrated the technical feasibility to detect L. (Viannia) parasites in mucosal and blood monocyte samples from patients with subclinical infections [157]. Recently, patients' urine was applied for molecular diagnosis by real-time PCR using samples of patients from Iran [158]. In this study, Leishmania DNA was detected and quantified in urine samples from patients with CL and VL, with a sensitivity of $89.2 \%$. Previously, a similar sensitivity was described (88\%) using urine samples of patients with VL and co-infected with HIV by conventional PCR [159].

For Leishmania species typing, real-time PCR was first applied by Weirather et al., [54]. In this study, authors evaluated a different combination of primers targeting kDNA minicircles and maxicircles and nuclear genes (in a total of 41 specific primer sets). A workflow with at least three serial real-time PCR was proposed, this being useful for identifying the main species responsible for VL and CL from serum and biopsy specimens respectively [54]. Although useful for discrimination of the main species endemic in Europe, Asia, and Africa, some species endemic in these regions were not evaluated, such as L. (L.) aethiopica in Africa and species of the subgenus Viannia autochthonous in the Amazon region: L. (V.) naiffi, L. (V.) lainsoni, L. (V.) shawi, and L. (V.) lindenbergi.

Some years later, a SYBR-Green assay targeting the ITS1 region of the parasite was validated for species discrimination, using reference strains and clinical isolates [53]. The proposed method was able to discriminate Leishmania in small groups containing 2-4 species, the main advantage being that this method can be accomplished by a single pair of primers, minimizing the risk of contamination [53]. This assay was incorporated into the CDC's algorithm for diagnosis of leishmaniasis, and for identification of the definitive species, the ITS2-PCR followed by sequencing was proposed [53].

\subsubsection{PCR-High Resolution Melting (HRM)}

PCR-HRM is a method based on variations in DNA sequences that uses double-stranded DNA binding dyes for measuring the intensity of fluorescence during dissociation of double-stranded to single-stranded DNA amplicons generated from a real-time PCR assay. This assay is performed with a new generation of saturating dyes (e.g., Eva Green or SYTO9) that needs specific equipment for PCR-HRM or an adapted real-time PCR instrument [107]. The method was established for discriminating the main species responsible for CL and VL in the Americas, Europe, Asia, and Africa. The main targets used for PCR-HRM were the hsp70, ITS1, and 7SL RNA genes [55-58]. Recently, this technology was also applied for identification and diagnosis of leishmaniasis using as a target an amino acid permease 3 (aap3) gene, an exclusive gene in trypanosomatids that is conserved in Leishmania [59]. The protocol was established using the main species responsible for CL and VL in the Americas, Europe, and Asia. The next goal for this technology is to implement it in endemic regions for its appropriated validation. It is a highly promising method, but requires an appropriate laboratory structure, with expensive equipment and trained professionals. Like other real-time PCR protocols, the results may be obtained quickly, with a reduced likelihood of contamination. 


\subsubsection{Loop-Mediated Isothermal Amplification (LAMP)}

This method is based on the amplification of DNA in less than one hour without the need for a thermocycler, this being a method already applied for other infectious diseases [160]. The amplified products can be detected visually using multiple parameters, including turbidity, fluorescence, and color with the naked eye and/or UV light [65]. LAMP is highly sensitive, with no postamplification handling or processing and may be implemented in endemic regions, with facilities requiring minimal structure for DNA extraction. It may be more sensitive than conventional PCR and has already been described as useful in the detection of Leishmania species and diagnosis of CL and VL (Table 1) [64-66]. Furthermore, this method may be used for the detection of RNA combining a reverse transcription step [9]. The main targets used are the 18S rRNA gene due to its high conservation in the genus Leishmania and elevated copy number, and minicircles, the main advantage of which is the high copy number per parasite, which increases the sensitivity of detection [65]. Recently, a LAMP assay targeting kDNA was described as able to detect the $L$. (L.) donovani, L. (L.) major, and L. (L.) tropica species [67]. The main limitation of LAMP is still the absence of a test able to discriminate different species of Leishmania in endemic regions where more than one species is present. A specific assay is only available for VL and/or PKDL due to L. (L.) donovani using kDNA minicircles as target [161].

\section{Immunological Methods for Diagnosis of Leishmaniasis}

Immunodiagnosis of leishmaniasis is based on the detection of antigens or anti-Leishmania antibodies in serum or urine samples from patients. Several immunological tests are available for diagnosis of leishmaniasis, particularly for VL, since it has a prominent humoral response [162]. In general, the methods used are: (i) Indirect fluorescent antibody test (IFAT); (ii) enzyme linked immunosorbent assay (ELISA); (iii) Western blot (or immunoblotting); (iv) direct agglutination test (DAT); (v) immunochromatographic strip test (ICT); and (vi) latex agglutination test (KAtex) (Table 1) $[35,163]$. The main challenges for immunological tests are cross-reactivity to other infectious diseases and false-positive results in some endemic areas [5,35]. Moreover, individuals co-infected with HIV can present negative results due to low antibody counts of the immunosuppressed condition $[17,163,164]$. Although serologic tests are available for CL, currently, they are not widely employed for CL diagnosis, considering that there is usually a poor humoral response from the host against parasites, meaning these tests exhibit low sensitivity [35]. New immunological tests are being developed to overcome this gap, using chemiluminescent ELISA to measure anti- $\alpha$-galactosyl antibodies or the CL Detect Rapid Test targeting the peroxidoxin antigen of the parasite [2].

\subsection{Leishmania Skin Test (LST)}

Used for almost a century, the LST (also known as the Montenegro skin test) is based on a delay-type hypersensitivity response for total antigens of Leishmania promastigotes. It presents high sensitivity and specificity values ( $86-100 \%$ and $>90 \%$, respectively), being useful for epidemiological studies [165]. Results are determined $48-72 \mathrm{~h}$ post-injection and positivity is confirmed if induration has a diameter higher than $5 \mathrm{~mm}$ at the inoculation site of antigens (Table 1) [16]. Asymptomatic and symptomatic patients infected with CL generally present a positive result (positivity higher than $80 \%$ ), while patients with DCL due to $L$. (L.) amazonensis have a LST negative result [16]. The test is also negative in patients with VL, becoming positive after successful treatment [166]. The major challenge for this test is its limitation in distinguishing present and previous infections, its use being restricted to people living in endemic areas.

\subsection{Methods for Detection of Anti-Leishmania Antibodies}

Methods for serological diagnosis have their sensitivity and specificity vary according to the method and antigens used, as well as to the host factors and the variations related to the species of Leishmania and the endemic region $[23,50,89,97,167]$. Serological tests have variable sensitivity due to 
antigenic differences in parasite species and low specificity due to cross-reactivity with other infectious diseases [168-171]. Serologic testing is recommended for VL patients when definitive diagnostic tests cannot be conducted or they have negative results [23]. The most accessible tests in routine practice for high income countries are ELISA, IFAT, indirect hemagglutination assay (IHA), and Western blot [27]. For this matter, recombinant proteins, such as the kinesin-related antigens rK39 and rK28, have been studied in order to develop faster and low-cost tests [172]. Moreover, serologic tests have a low sensitivity to VL diagnosis in HIV-infected patients and, therefore, tests for antileishmanial antibodies should not be performed as the only diagnostic assay, due to the potential for false-negative results $[23,164]$. Interestingly, recent studies have reported the potential use of urine for the detection of antibodies in VL, PKDL, and CL patients $[158,173]$.

\subsubsection{Direct Agglutination Test (DAT)}

The DAT is based on the agglutination reaction between antigen and antibody. For VL due to L. (L.) infantum and $L$. (L.) donovani, this test can be easily performed using serum or urine samples of patients [163]. This method showed high sensitivity (74.6-96.6\%) and specificity $(77.8-100 \%)$ in patients from Brazil, Spain, Kenya, Sudan, Ethiopia, and Nepal $[50,71,86,87,90,91]$. This test is also useful as marker of asymptomatic infection and in HIV co-infected individuals, showing sensitivity and specificity values of $81-91.3 \%$ and $83.3-90 \%$, respectively $[86,164,174,175]$. Some limitations of this technique include the use of whole parasite antigen, which increases cross-reactivity with other infectious diseases, the need for serial dilutions, and a long incubation period [176]. Later, this method was improved for the Fast Agglutination Screening Test (FAST), with a shorter incubation period [177]. Another limitation is that this test remains positive up to one year after a clinical cure, so it cannot be used as a follow-up treatment, cure, or relapse [178]. Regarding diagnostic methods, DAT for CL using the L. (L.) aethiopica antigen showed high sensitivity $(90.5 \%)$ and specificity $(91.8 \%)$ in patients infected with this species; however, when the $L$. (L.) donovani antigen was used, a low sensitivity was found [179]. In Brazil, DAT and FAST were assayed to evaluate antibodies in patients with CL from an endemic area, but neither of these tests were useful for the diagnosis of this clinical form of the disease [180].

\subsubsection{Indirect Hemagglutination Assay (IHA)}

The IHA uses sheep erythrocytes sensitized with a soluble Leishmania antigen, which are used for hemagglutination and for determining antibody titers [181]. It is considered sensitive and reliable in the detection of antileishmanial antibodies; however, it does not confirm the presence of parasites or parasite antigens, thus, it only indicates the exposure of the patient to the parasite [182]. It is well documented that individuals with VL may remain seropositive by IHA for periods of months or years; therefore, IHA is not sufficient as a sole diagnostic test for patients with clinically suspected VL [88]. Furthermore, this method has shown inferior performance in comparison with the microscopic detection of amastigotes in the bone marrow smear examination [182]. Sensitivity of IHA can vary according to the immune response of the host, for instance, the nutritional status can affect the immunoglobulin production rate. Poor nutritional status can lead to a low immune response and, hence, a low rate of immunoglobulins, which could explain the low IHA titer in these patients and false-negative results. Additionally, cross-reactions may be considered in regions where there are other endemic diseases, such as leprosy, Chagas disease, malaria, and schistosomiasis [183].

\subsubsection{Indirect Fluorescent Antibody Test (IFAT)}

The main advantage of the IFAT is the possibility to discriminate between a cure and a possible relapse in VL. This test does not detect antibodies in VL patients' samples after a cure and the persistence of antibodies in the serum indicates a possible relapse [24]. Its sensitivity and specificity are variable and the values are $28.4-92 \%$ and $83.3-94.4 \%$, respectively, in immunocompetent patients from different endemic areas (Table 1) [71,86-88]. Meanwhile, in a meta-analysis study with HIV/VL co-infected 
patients, this test demonstrated highly variable values, with sensitivity and specificity of $11-82 \%$ and 81-99\%, respectively [164]. Later, an in-house IFAT using antigens prepared from promastigotes of L. (L.) infantum showed a sensitivity of $79.4 \%$ and a specificity of $99.2 \%$ with serum of HIV/VL patients from Spain [86].

In patients from Brazil with ML, IFAT showed a sensitivity of 56.7\% [184]. In another study conducted with Brazilian patients with CL or ML, it achieved sensitivity and specificity levels of $95.4 \%$ and $77.7 \%$, respectively, when $L$. (L.) major promastigote antigens were used, with L. (V.) braziliensis promastigotes being used as antigens, it presented a sensitivity of $81.5 \%$ and a specificity of $86.2 \%$ [89].

\subsubsection{Enzyme Linked Immunosorbent Assay (ELISA)}

The ELISA sensitivity and specificity vary depending upon the antigen used [176]. The advantage of ELISA is that it can be used for a large number of samples with different antigens and different types of samples at the same time [163]. On the other hand, the disadvantages include the time necessary, the need for specialized professionals, sophisticated equipment, and the lack of discrimination between an active disease and the clinical cure, with its use being limited in endemic regions [176].

For VL diagnosis, the rK39 antigen is mostly used, a 39-amino acid containing a kinesin-related peptide of L. (L.) infantum [185]. The sensitivity and specificity of ELISA-rK39 vary around 88.6-99\% and 81-98.2\%, respectively, in endemic regions for VL due to L. (L.) infantum and L. (L.) donovani [68-73]. In patients infected by L. (L.) infantum who are co-infected with HIV, the rK39 antigen had a sensitivity of $82 \%$ [186]. Other recombinant proteins, such as rK26, rKRP42, rK9, rKE16, rA2, and rKDDR, among others, were also tested and showed varied sensitivity in VL patients [74-78]. The BHUP1 antigen, a heat shock protein, showed 95\% sensitivity and 96-100\% specificity, using sera from untreated and successfully treated patients from a VL endemic area in India [82]. Other antigens of this same family of proteins, BHUP2 and BHUP3, also showed satisfactory sensitivity (88-94\%) and specificity (96-100\%) for diagnosis of VL $[81,83]$. The heat shock proteins HSP70 and HSP83 proved to be good candidates for VL diagnosis. In the case of rHSP83, it is recognized in sera of CL, ML, and VL patients, with an insignificant cross-reaction with other diseases $[79,80]$. In a recent study, a hypothetical protein from L. (L.) infantum (LiHyE) showed good results in terms of sensitivity in samples from patients with CL and VL, when compared to other antigens. This recombinant protein was considered to be a promising marker for differentiating healthy individuals from those infected with CL or VL [187,188].

As an alternative for the detection of antibodies in the serum, a urine ELISA assay was developed for diagnosis of anti-Leishmania antibodies. For VL, the sensitivity and specificity of this assay were 97.94\% and 100\%, respectively, while for PKDL, sensitivity and specificity were 100\% [158]. This assay is based on a Leishmania promastigote membrane antigen that showed the best recognition of IgG antibodies compared to other tested antigens [recombinant GP63 and CPA (cysteine protease) proteins and soluble leishmanial antigens from L. (L.) donovani] [158].

In patients with ML, ELISA presented a sensitivity of $93.3 \%$ using the total antigen of L. (L.) major promastigotes [184], whereas amongst patients with CL, the sensitivity of this same test was only $66.3 \%$ [167]. In patients with CL caused by L. (L.) tropica, ELISA using total antigens of L. (L.) infantum promastigotes, showed sensitivity and specificity of $78 \%$ and $95.3 \%$, respectively [97]. ELISA serology in Brazilian CL/HIV co-infected patients showed a sensitivity of $77 \%$ [189]. Sensitivity of $95.7 \%$ and specificity of $100 \%$ was achieved using L. (V.) braziliensis total antigens, while with L. (L.) major, lower values of sensitivity (78.7\%) and specificity were observed (78.7\% and $82.8 \%$, respectively) for diagnosis of Brazilian patients with CL and ML [89]. Alternative antigens, such as HSP60 of L. (L.) major and HSP70 of L. (V.) braziliensis, were shown to be good candidates, although cross-reactivity may occur with the serum of patients with VL [190,191]. Recombinant proteins of L. (L.) infantum, such as HSP70, histone proteins, and a protein of the kinetoplast (KMP11), were also tested using sera from patients with CL, with HSP70 showing the best performance [170]. Another study using the recombinant version of the HSP83.1 protein from L. (V.) braziliensis showed that it is a promising antigen for the immunodiagnosis of both clinical forms of leishmaniasis [192]. 
Recombinant proteins from $L$. (V.) braziliensis were evaluated for CL diagnosis, using serum from patients with CL and ML [84,85]. Among the several proteins identified as antigenic, tryparedoxin peroxidase showed the best result, with $100 \%$ sensitivity and specificity [84]. The reactivity of rLb8E and $\mathrm{rLb} 6 \mathrm{H}$ antigens from $L .(V$.$) braziliensis was evaluated in CL patients [85]. Both antigens showed$ good performance, however, $\mathrm{rLb6H}$ showed greater reactivity with $L$. (L.) amazonensis, followed by L. (V.) braziliensis and L. (V.) guyanensis. Other recombinant proteins, such as LiHypA, SMP-3, CcOx, $\mathrm{HRF}, \mathrm{rLiHyL}$, and others, were evaluated and presented good results, with some studies observing good sensitivity and specificity for both CL and VL [187,193-195]. In general, these recombinant proteins have higher sensitivity and specificity than the soluble Leishmania antigen extract, but they do not discriminate CL and VL infection.

\subsubsection{Immuno-Chromatographic Test (ICT) (Strip Test)}

The ICT using rK39 antigen is widely used in the diagnosis of VL, however its sensitivity and specificity may vary depending on the product and patient's origin, as demonstrated in studies with patients from different endemic areas in Brazil, Spain, East Africa, and Southeast Asia (Table 1) $[50,70,86,90,92,196]$. In HIV positive patients from Spain, $67.3 \%$ sensitivity and $100 \%$ specificity were observed [86].

The advantage of this test includes low cost, rapid, easy and simple performance. Similar to ELISA, this test does not discriminate between the active disease and the clinical cure, restricting its use in endemic regions [176]. Other recombinant antigens, such as rK28, were evaluated for the immunochromatographic assay (or lateral flow immunoassay) [197-200]. As an alternative, a dipstick test containing $L$. (L.) donovani membrane antigens was developed, presenting sensitivity and specificity of $100 \%$ in Indian and Brazilian patients with VL (Table 1) [94]. This test was evaluated later for $\mathrm{VL}$, using sera from more than 1000 subjects from eight centers in six endemic countries (India, Nepal, Sri Lanka, Brazil, Ethiopia, and Spain) [93]. The overall sensitivity and specificity for all these regions were $97.1 \%$ and $93.44 \%$, respectively, and a better performance of this test was found compared to the rK39 rapid test (see below) in these regions [93]. More important, the dipstick test did not cross react with serum samples of patients with CL. Previously a dipstick test was described using this same antigen for detection of antibodies in the urine of patients with VL and PKDL with a sensitivity of $100 \%$ [173]. The main membrane antigens recognized by serum from VL patients were characterized by mass spectrometry and included the receptor of activated $C$ kinase (LACK), beta-tubulin isoforms, ATP synthase $\alpha$-chain, elongation factor 1- $\alpha$ (EF1- $\alpha)$, GP63, HSP70, and nucleoporins-93 (NUP-93) [201-204].

More recently, laser direct-write technology was used for the development of a new lateral flow immunoassay device containing the recombinant proteins $\beta$-tubulin and LiHyp1. This device is less expensive than other immuno-chromatographic tests and presented high sensitivity $(90.9 \%)$ and specificity (98.7\%) using blood/serum from patients diagnosed with VL [205].

\subsection{6. rK39 Rapid Diagnostic Test (RDT)}

The K39 protein provides the basis for the developed rK39 RDT. The result arrives between 10 and $20 \mathrm{~min}$ in the form of a binary reading (positive or negative), with sensitivity estimated at $97 \%$ in India and 85\% in Eastern Africa [206]. The rK39 RDT is the most widely used tool and the first choice for a decentralized diagnosis of VL in endemic areas, but it cannot discriminate between current, subclinical, or past infections [207]. This test was applied for evaluation of Leishmania asymptomatic infection in HIV patients from an endemic area in Ethiopia [208]. The rK39 RDT was considered the most common marker for asymptomatic infection in these patients, compared to DAT and KAtex (see below), and real-time PCR [209]. In the northeastern region of Brazil, the sensitivity in VL/HIV co-infected patients was low when compared with patients with $\mathrm{VL}$ and sensitivity was $0.0 \%$ and $25 \%$ using oral fluid and serum/whole blood, respectively, while for VL patients the sensitivity ranged from $80 \%$ to $96.3 \%$ using whole blood and serum and $43.3 \%$ to $88.9 \%$ in oral fluid, depending on the origin 
of these Brazilian patients [210]. This variation in sensitivity may be explained by the extensive kinesin genetic diversity in strains and isolates of Leishmania, as described for different L. (L.) donovani strains from East Africa and South Asia [209]. These findings highlight the importance of considering the use of this test in particular endemic areas.

\subsubsection{Western Blot}

Western blot has high sensitivity (98\%) and specificity (100\%) and can be more sensitive than IFAT and ELISA (Table 1) [95-97]. In HIV/Leishmania co-infected patients the sensitivity and specificity were $84 \%$ and $82 \%$, respectively [164]. Serum of CL patients due to L. (L.) tropica infection detected proteins of 15-118 kDa of an antigenic extract of L. (L.) infantum promastigotes [97]. Among these proteins, a band of $63 \mathrm{kDa}$ had the highest sensitivity (99.1\%) [97]. Recently, serum samples from VL patients were used to detect 34 protein bands by Western blot using L. (L.) infantum promastigotes extract [98]. In addition to this, urine from CL and VL patients from Iran was recently described as useful for detection of antibodies against the parasite by Western blot using L. (L.) infantum extract, with sensitivity $78.2 \%$ and $92.8 \%$ for CL and VL, respectively [158]. The main advantage of Western blot is the detailed antibodies' responses to various antigens. However, it is a time consuming and expensive process, besides needing qualified professionals [176].

\subsection{Methods for Detection of Antigens of Leishmania}

Antigen detection can be considered more specific than antibody-based immunodiagnostic tests and is also useful in the diagnosis of the disease in cases where there is deficient antibody production (as in HIV patients) [211]. A latex test (KAtex) based on detection of a heat-stable low molecular-weight carbohydrate antigen in urine samples has been developed [165]. This KAtex assay showed varying sensitivity $(35.8 \%-100 \%)$ and specificity $(64 \%-98.3 \%)$, depending on the endemic region (Table 1) [49-51]. Interestingly, more than $90 \%$ of cured patients had a negative KAtex result [51], indicating that this method may discriminate current disease and clinical cure of VL. In addition, in HIV/Leishmania co-infected individuals, this test showed good sensitivity (85.7\%-100\%) [211-213]. The test is simple, easy to perform, inexpensive, quick, and can be used as a screening test, since specificity can be high, but it has low to moderate sensitivity [176]. Furthermore, it also contributes to improving VL diagnosis and monitoring treatment response in HIV co-infected patients, reducing the exposure to invasive procedures amongst these vulnerable individuals [214].

Other antigens were previously identified in the urine (Li-isd1, Li-txn-1, and Li-ntf2) of VL patients infected with $L$. (L.) infantum. These antigens were used as recombinant proteins for the production of antibodies and to develop a capture ELISA for detection of these proteins in the urine of VL patients. This method presented sensitivity and specificity of $89 \%$ and $100 \%$, respectively, and a limit of detection of 4-10 pg of antigen per $\mathrm{mL}$ of urine $[215,216]$. This assay was improved by including other three proteins (Ld-mao1, Ld-ppi1, and Ld-mad1) for the production of an antigen detection capture ELISA for diagnosis of VL caused by L. (L.) infantum and L. (L.) donovani [217]. This multiplexed capture ELISA based on monoclonal antibodies is able to simultaneously detect these six proteins in the urine of patients and had a sensitivity higher than 93\% [217]. This test did not cross-react with the urine of healthy individuals or of patients with non-VL tropical diseases, and it has been proposed that it should be validated in clinical use [217]. Recently another six proteins were identified by mass spectrometry (40S ribosomal protein S9, two protein kinases, and another four hypothetical proteins) from urine samples of Indian and Sudanese VL patients, being used to predict epitope regions highly specific to Leishmania spp. and suitable for raising antibodies for the development of an antigen capture assay [218].

\section{Conclusions}

Several methods and tools have been developed over recent years for the detection, quantification, and identification of the parasite of the genus Leishmania. Although advances in these methods have 
improved the sensitivity and specificity of leishmaniasis diagnosis, there are still some challenges to be overcome. For instance, developing affordable, fast, and accessible tests that can define Leishmania species will be a turning point in diagnosis, since the discrimination of species has significant importance for prognosis and species-specific treatments. Parasitological and microscopic examinations are broadly used; although highly specific, they present insufficient sensitivity and do not provide Leishmania species identification. Furthermore, biopsies can be very invasive and life-threatening, such as in some patients with VL. In vitro and in vivo cultivation are rarely used in routine clinical practice, given that they are generally only available in leishmaniasis diagnosis reference centers and the results can take weeks to be delivered. To fill the gap of non-invasive tests and define Leishmania species, molecular tests are promising and already available, but remain reserved for reference laboratories and are usually found only in high-income countries. Alternatively, rapid tests are promising to deliver non-invasive and low-priced methods, but there are still limitations in endemic regions due to false positives. Therefore, there is a need for a simple, fast, and accurate test with high sensitivity and specificity, which can be used without any specific expertise, considering the conditions that prevail in endemic areas, where sophisticated methods cannot be employed.

Author Contributions: All authors contributed to the manuscript. Conceptualization: J.Q.R. and A.C.C.; investigation, resources, data curation, writing: all authors; review and editing: J.Q.R. and A.C.C.; funding acquisition: J.Q.R. and A.C.C. All authors have read and agreed to the published version of the manuscript.

Funding: This work was supported by the Fundação de Amparo à Pesquisa do Estado de São Paulo (FAPESP) (grant numbers 2016/21171-6 and 2018/18954-4). A.C.C. has also, in part, received funding from UK Research and Innovation via the Global Challenges Research Fund under grant agreement 'A Global Network for Neglected Tropical Diseases' (grant number MR/P027989/1). E.M.C. is currently supported by a CAPES fellowship (process number 88887.510830/2020-00).

Conflicts of Interest: The authors declare no conflict of interest.

\section{References}

1. Akhoundi, M.; Kuhls, K.; Cannet, A.; Votýpka, J.; Marty, P.; Delaunay, P.; Sereno, D. A Historical Overview of the Classification, Evolution, and Dispersion of Leishmania Parasites and Sandflies. PLoS Negl. Trop. Dis. 2016, 10, e0004349. [CrossRef] [PubMed]

2. Burza, S.; Croft, S.L.; Boelaert, M. Leishmaniasis. Lancet 2018, 392, 951-970. [CrossRef]

3. Alvar, J.; Velez, I.D.; Bern, C.; Herrero, M.; Desjeux, P.; Cano, J.; Jannin, J.; den Boer, M. Leishmaniasis worldwide and global estimates of its incidence. PLOS ONE 2012, 7, e35671. [CrossRef] [PubMed]

4. Karimkhani, C.; Wanga, V.; Coffeng, L.E.; Naghavi, P.; Dellavalle, R.P.; Naghavi, M. Global burden of cutaneous leishmaniasis: A cross-sectional analysis from the Global Burden of Disease Study 2013. Lancet Infect. Dis. 2016, 16, 584-591. [CrossRef]

5. Chappuis, F.; Sundar, S.; Hailu, A.; Ghalib, H.; Rijal, S.; Peeling, R.W.; Alvar, J.; Boelaert, M. Visceral leishmaniasis: What are the needs for diagnosis, treatment and control? Nat. Rev. Microbiol. 2007, 5, 873-882. [CrossRef]

6. Jambulingam, P.; Pradeep Kumar, N.; Nandakumar, S.; Paily, K.P.; Srinivasan, R. Domestic dogs as reservoir hosts for Leishmania donovani in the southernmost Western Ghats in India. Acta Trop. 2017, 171, 64-67. [CrossRef]

7. Mukhopadhyay, D.; Dalton, J.E.; Kaye, P.M.; Chatterjee, M. Post kala-azar dermal leishmaniasis: An unresolved mystery. Trends Parasitol. 2014, 30, 65-74. [CrossRef]

8. Zijlstra, E.E. The immunology of post-kala-azar dermal leishmaniasis (PKDL). Parasites Vectors 2016, 9, 464. [CrossRef]

9. Akhoundi, M.; Downing, T.; Votýpka, J.; Kuhls, K.; Lukeš, J.; Cannet, A.; Ravel, C.; Marty, P.; Delaunay, P.; Kasbari, M.; et al. Leishmania infections: Molecular targets and diagnosis. Mol. Asp. Med. 2017, 57, 1-29. [CrossRef]

10. Hotez, P.J.; Savioli, L.; Fenwick, A. Neglected tropical diseases of the Middle East and North Africa: Review of their prevalence, distribution, and opportunities for control. PLoS Negl. Trop. Dis. 2012, 6, e1475. [CrossRef] 
11. Silveira, F.T. What makes mucosal and anergic diffuse cutaneous leishmaniases so clinically and immunopathogically different? A review in Brazil. Trans. R. Soc. Trop. Med. Hyg. 2019. [CrossRef] [PubMed]

12. Reithinger, R.; Dujardin, J.C.; Louzir, H.; Pirmez, C.; Alexander, B.; Brooker, S. Cutaneous leishmaniasis. Lancet Infect. Dis. 2007, 7, 581-596. [CrossRef]

13. Turetz, M.L.; Machado, P.R.; Ko, A.I.; Alves, F.; Bittencourt, A.; Almeida, R.P.; Mobashery, N.; Johnson, W.D., Jr.; Carvalho, E.M. Disseminated leishmaniasis: A new and emerging form of leishmaniasis observed in northeastern Brazil. J. Infect. Dis. 2002, 186, 1829-1834. [CrossRef]

14. Desjeux, P. The increase in risk factors for leishmaniasis worldwide. Trans. R. Soc. Trop. Med. Hyg. 2001, 95, 239-243. [CrossRef]

15. Desjeux, P.; Alvar, J. Leishmania/HIV co-infections: Epidemiology in Europe. Ann. Trop. Med. Parasitol. 2003, 97 (Suppl. 1), 3-15. [CrossRef] [PubMed]

16. Goto, H.; Lindoso, J.A. Current diagnosis and treatment of cutaneous and mucocutaneous leishmaniasis. Expert Rev. Anti-Infect. Ther. 2010, 8, 419-433. [CrossRef] [PubMed]

17. Alvar, J.; Canavate, C.; Gutierrez-Solar, B.; Jimenez, M.; Laguna, F.; Lopez-Velez, R.; Molina, R.; Moreno, J. Leishmania and human immunodeficiency virus coinfection: The first 10 years. Clin. Microbiol. Rev. 1997, 10, 298-319. [CrossRef]

18. Lindoso, J.A.; Cota, G.F.; da Cruz, A.M.; Goto, H.; Maia-Elkhoury, A.N.; Romero, G.A.; de Sousa-Gomes, M.L.; Santos-Oliveira, J.R.; Rabello, A. Visceral leishmaniasis and HIV coinfection in Latin America. PLoS Negl. Trop. Dis. 2014, 8, e3136. [CrossRef]

19. Sundar, S.; Rai, M. Laboratory diagnosis of visceral leishmaniasis. Clin. Diagn. Lab. Immunol. 2002, 9, 951-958. [CrossRef]

20. Jarvis, J.N.; Lockwood, D.N. Clinical aspects of visceral leishmaniasis in HIV infection. Curr. Opin. Infect. Dis. 2013, 26, 1-9. [CrossRef]

21. Uliana, S.R.B.; Trinconi, C.T.; Coelho, A.C. Chemotherapy of leishmaniasis: Present challenges. Parasitology 2018, 145, 464-480. [CrossRef] [PubMed]

22. Romero, G.A.; Vinitius De Farias Guerra, M.; Gomes Paes, M.; de Oliveira Macêdo, V. Comparison of cutaneous leishmaniasis due to Leishmania (Viannia) braziliensis and L. (V.) guyanensis in Brazil: Clinical findings and diagnostic approach. Clin. Infect. Dis. 2001, 32, 1304-1312. [CrossRef] [PubMed]

23. Aronson, N.; Herwaldt, B.L.; Libman, M.; Pearson, R.; Lopez-Velez, R.; Weina, P.; Carvalho, E.M.; Ephros, M.; Jeronimo, S.; Magill, A. Diagnosis and Treatment of Leishmaniasis: Clinical Practice Guidelines by the Infectious Diseases Society of America (IDSA) and the American Society of Tropical Medicine and Hygiene (ASTMH). Clin. Infect. Dis. 2016, 63, 1539-1557. [CrossRef] [PubMed]

24. Srivastava, P.; Dayama, A.; Mehrotra, S.; Sundar, S. Diagnosis of visceral leishmaniasis. Trans. R. Soc. Trop. Med. Hyg. 2011, 105, 1-6. [CrossRef]

25. Suárez, M.; Valencia, B.M.; Jara, M.; Alba, M.; Boggild, A.K.; Dujardin, J.C.; Llanos-Cuentas, A.; Arevalo, J.; Adaui, V. Quantification of Leishmania (Viannia) Kinetoplast DNA in Ulcers of Cutaneous Leishmaniasis Reveals Inter-site and Inter-sampling Variability in Parasite Load. PLoS Negl. Trop. Dis. 2015, 9, e0003936. [CrossRef]

26. Sousa, A.Q.; Pompeu, M.M.; Frutuoso, M.S.; Lima, J.W.; Tinel, J.M.; Pearson, R.D. Press imprint smear: A rapid, simple, and cheap method for the diagnosis of cutaneous leishmaniasis caused by Leishmania (Viannia) braziliensis. Am. J. Trop. Med. Hyg. 2014, 91, 905-907. [CrossRef]

27. van Griensven, J.; Diro, E. Visceral Leishmaniasis: Recent Advances in Diagnostics and Treatment Regimens. Infect. Dis. Clin. N. Am. 2019, 33, 79-99. [CrossRef]

28. Control of the Leishmaniases. Report of a WHO Expert Committee. World Health Organ. Tech. Rep. Ser. 2010, 949, 1-186.

29. Saab, M.; El Hage, H.; Charafeddine, K.; Habib, R.H.; Khalifeh, I. Diagnosis of cutaneous leishmaniasis: Why punch when you can scrape? Am. J. Trop. Med. Hyg. 2015, 92, 518-522. [CrossRef]

30. Sandoval Pacheco, C.M.; Araujo Flores, G.V.; Favero Ferreira, A.; Sosa Ochoa, W.; Ribeiro da Matta, V.L.; Zúniga Valeriano, C.; Pereira Corbett, C.E.; Dalastra Laurenti, M. Histopathological features of skin lesions in patients affected by non-ulcerated or atypical cutaneous leishmaniasis in Honduras, Central America. Int. J. Exp. Pathol. 2018, 99, 249-257. [CrossRef] 
31. Ramírez, J.R.; Agudelo, S.; Muskus, C.; Alzate, J.F.; Berberich, C.; Barker, D.; Velez, I.D. Diagnosis of cutaneous leishmaniasis in Colombia: The sampling site within lesions influences the sensitivity of parasitologic diagnosis. J. Clin. Microbiol. 2000, 38, 3768-3773. [CrossRef] [PubMed]

32. Nateghi Rostami, M.; Darzi, F.; Farahmand, M.; Aghaei, M.; Parvizi, P. Performance of a universal PCR assay to identify different Leishmania species causative of Old World cutaneous leishmaniasis. Parasites Vectors 2020, 13, 431. [CrossRef]

33. da Silva, M.R.; Stewart, J.M.; Costa, C.H. Sensitivity of bone marrow aspirates in the diagnosis of visceral leishmaniasis. Am. J. Trop. Med. Hyg. 2005, 72, 811-814. [CrossRef] [PubMed]

34. Babiker, Z.O.; Davidson, R.; Mazinda, C.; Kipngetich, S.; Ritmeijer, K. Utility of lymph node aspiration in the diagnosis of visceral leishmaniasis in Sudan. Am. J. Trop. Med. Hyg. 2007, 76, 689-693. [CrossRef] [PubMed]

35. de Vries, H.J.; Reedijk, S.H.; Schallig, H.D. Cutaneous leishmaniasis: Recent developments in diagnosis and management. Am. J. Clin. Dermatol. 2015, 16, 99-109. [CrossRef] [PubMed]

36. Hockmeyer, W.T.; Kager, P.A.; Rees, P.H.; Hendricks, L.D. The culture of Leishmania donovani in Schneider's insect medium: Its value in the diagnosis and management of patients with visceral leishmaniasis. Trans. $R$. Soc. Trop. Med. Hyg. 1981, 75, 861-863. [CrossRef]

37. Schuster, F.L.; Sullivan, J.J. Cultivation of clinically significant hemoflagellates. Clin. Microbiol. Rev. 2002, 15, 374-389. [CrossRef]

38. Pagheh, A.; Fakhar, M.; Mesgarian, F.; Gholami, S.; Ahmadpour, E. An improved microculture method for diagnosis of cutaneous leishmaniasis. J. Parasit. Dis. 2014, 38, 347-351. [CrossRef]

39. Mondal, D.; Bern, C.; Ghosh, D.; Rashid, M.; Molina, R.; Chowdhury, R.; Nath, R.; Ghosh, P.; Chapman, L.A.C.; Alim, A.; et al. Quantifying the Infectiousness of Post-Kala-Azar Dermal Leishmaniasis toward Sand Flies. Clin. Infect. Dis. 2019, 69, 251-258. [CrossRef]

40. Singh, O.P.; Hasker, E.; Boelaert, M.; Sacks, D.; Sundar, S. Xenodiagnosis to address key questions in visceral leishmaniasis control and elimination. PLoS Negl. Trop. Dis. 2020, 14, e0008363. [CrossRef]

41. Cupolillo, E.; Grimaldi, G., Jr.; Momen, H. A general classification of New World Leishmania using numerical zymotaxonomy. Am. J. Trop. Med. Hyg. 1994, 50, 296-311. [CrossRef] [PubMed]

42. Grimaldi, G.; McMahon-Pratt, D. Monoclonal antibodies for the identification of New World Leishmania species. Memórias Inst. Oswaldo Cruz 1996, 91, 37-42. [CrossRef] [PubMed]

43. Jaffe, C.L.; Bennett, E.; Grimaldi, G., Jr.; McMahon-Pratt, D. Production and characterization of species-specific monoclonal antibodies against Leishmania donovani for immunodiagnosis. J. Immunol. 1984, 133, 440-447. [PubMed]

44. Jaffe, C.L.; McMahon-Pratt, D. Monoclonal antibodies specific for Leishmania tropica. I. Characterization of antigens associated with stage- and species-specific determinants. J. Immunol. 1983, 131, 1987-1993.

45. Jaffe, C.L.; Rachamim, N. Amastigote stage-specific monoclonal antibodies against Leishmania major. Infect. Immun. 1989, 57, 3770-3777. [CrossRef]

46. Cassagne, C.; Pratlong, F.; Jeddi, F.; Benikhlef, R.; Aoun, K.; Normand, A.C.; Faraut, F.; Bastien, P.; Piarroux, R. Identification of Leishmania at the species level with matrix-assisted laser desorption ionization time-of-flight mass spectrometry. Clin. Microbiol. Infect. 2014, 20, 551-557. [CrossRef] [PubMed]

47. Lachaud, L.; Fernández-Arévalo, A.; Normand, A.C.; Lami, P.; Nabet, C.; Donnadieu, J.L.; Piarroux, M.; Djenad, F.; Cassagne, C.; Ravel, C.; et al. Identification of Leishmania by Matrix-Assisted Laser Desorption Ionization-Time of Flight (MALDI-TOF) Mass Spectrometry Using a Free Web-Based Application and a Dedicated Mass-Spectral Library. J. Clin. Microbiol. 2017, 55, 2924-2933. [CrossRef]

48. Mouri, O.; Morizot, G.; Van der Auwera, G.; Ravel, C.; Passet, M.; Chartrel, N.; Joly, I.; Thellier, M.; Jauréguiberry, S.; Caumes, E.; et al. Easy identification of Leishmania species by mass spectrometry. PLoS Negl. Trop. Dis. 2014, 8, e2841. [CrossRef]

49. Attar, Z.J.; Chance, M.L.; el-Safi, S.; Carney, J.; Azazy, A.; El-Hadi, M.; Dourado, C.; Hommel, M. Latex agglutination test for the detection of urinary antigens in visceral leishmaniasis. Acta Trop. 2001, 78, 11-16. [CrossRef]

50. Boelaert, M.; El-Safi, S.; Hailu, A.; Mukhtar, M.; Rijal, S.; Sundar, S.; Wasunna, M.; Aseffa, A.; Mbui, J.; Menten, J.; et al. Diagnostic tests for kala-azar: A multi-centre study of the freeze-dried DAT, rK39 strip test and KAtex in East Africa and the Indian subcontinent. Trans. R. Soc. Trop. Med. Hyg. 2008, 102, 32-40. [CrossRef] 
51. Salam, M.A.; Khan, M.G.; Mondal, D. Urine antigen detection by latex agglutination test for diagnosis and assessment of initial cure of visceral leishmaniasis. Trans. R. Soc. Trop. Med. Hyg. 2011, 105, 269-272. [CrossRef] [PubMed]

52. Van der Auwera, G.; Dujardin, J.C. Species typing in dermal leishmaniasis. Clin. Microbiol. Rev. 2015, 28, 265-294. [CrossRef] [PubMed]

53. de Almeida, M.E.; Koru, O.; Steurer, F.; Herwaldt, B.L.; da Silva, A.J. Detection and Differentiation of Leishmania spp. in Clinical Specimens by Use of a SYBR Green-Based Real-Time PCR Assay. J. Clin. Microbiol. 2017, 55, 281-290. [CrossRef] [PubMed]

54. Weirather, J.L.; Jeronimo, S.M.; Gautam, S.; Sundar, S.; Kang, M.; Kurtz, M.A.; Haque, R.; Schriefer, A.; Talhari, S.; Carvalho, E.M.; et al. Serial quantitative PCR assay for detection, species discrimination, and quantification of Leishmania spp. in human samples. J. Clin. Microbiol. 2011, 49, 3892-3904. [CrossRef] [PubMed]

55. Talmi-Frank, D.; Nasereddin, A.; Schnur, L.F.; Schönian, G.; Töz, S.O.; Jaffe, C.L.; Baneth, G. Detection and identification of old world Leishmania by high resolution melt analysis. PLoS Negl. Trop. Dis. 2010, 4, e581. [CrossRef]

56. Hernández, C.; Alvarez, C.; González, C.; Ayala, M.S.; León, C.M.; Ramírez, J.D. Identification of six New World Leishmania species through the implementation of a High-Resolution Melting (HRM) genotyping assay. Parasites Vectors 2014, 7, 501. [CrossRef]

57. Zampieri, R.A.; Laranjeira-Silva, M.F.; Muxel, S.M.; Stocco de Lima, A.C.; Shaw, J.J.; Floeter-Winter, L.M. High Resolution Melting Analysis Targeting hsp70 as a Fast and Efficient Method for the Discrimination of Leishmania Species. PLoS Negl. Trop. Dis. 2016, 10, e0004485. [CrossRef]

58. Nasereddin, A.; Jaffe, C.L. Rapid diagnosis of Old World Leishmaniasis by high-resolution melting analysis of the 7SL RNA gene. J. Clin. Microbiol. 2010, 48, 2240-2242. [CrossRef]

59. Müller, K.E.; Zampieri, R.A.; Aoki, J.I.; Muxel, S.M.; Nerland, A.H.; Floeter-Winter, L.M. Amino acid permease 3 (aap3) coding sequence as a target for Leishmania identification and diagnosis of leishmaniases using high resolution melting analysis. Parasites Vectors 2018, 11, 421. [CrossRef]

60. Boite, M.C.; Mauricio, I.L.; Miles, M.A.; Cupolillo, E. New insights on taxonomy, phylogeny and population genetics of Leishmania (Viannia) parasites based on multilocus sequence analysis. PLoS Negl. Trop. Dis. 2012, 6, e1888. [CrossRef]

61. Mauricio, I.L.; Yeo, M.; Baghaei, M.; Doto, D.; Pratlong, F.; Zemanova, E.; Dedet, J.P.; Lukes, J.; Miles, M.A. Towards multilocus sequence typing of the Leishmania donovani complex: Resolving genotypes and haplotypes for five polymorphic metabolic enzymes (ASAT, GPI, NH1, NH2, PGD). Int. J. Parasitol. 2006, 36, 757-769. [CrossRef] [PubMed]

62. Zemanová, E.; Jirků, M.; Mauricio, I.L.; Horák, A.; Miles, M.A.; Lukes, J. The Leishmania donovani complex: Genotypes of five metabolic enzymes (ICD, ME, MPI, G6PDH, and FH), new targets for multilocus sequence typing. Int. J. Parasitol. 2007, 37, 149-160. [CrossRef] [PubMed]

63. Tsukayama, P.; Lucas, C.; Bacon, D.J. Typing of four genetic loci discriminates among closely related species of New World Leishmania. Int. J. Parasitol. 2009, 39, 355-362. [CrossRef] [PubMed]

64. Khan, M.G.; Bhaskar, K.R.; Salam, M.A.; Akther, T.; Pluschke, G.; Mondal, D. Diagnostic accuracy of loop-mediated isothermal amplification (LAMP) for detection of Leishmania DNA in buffy coat from visceral leishmaniasis patients. Parasites Vectors 2012, 5, 280. [CrossRef]

65. Nzelu, C.O.; Kato, H.; Peters, N.C. Loop-mediated isothermal amplification (LAMP): An advanced molecular point-of-care technique for the detection of Leishmania infection. PLoS Negl. Trop. Dis. 2019, 13, e0007698. [CrossRef]

66. Adams, E.R.; Schoone, G.; Versteeg, I.; Gomez, M.A.; Diro, E.; Mori, Y.; Perlee, D.; Downing, T.; Saravia, N.; Assaye, A.; et al. Development and Evaluation of a Novel Loop-Mediated Isothermal Amplification Assay for Diagnosis of Cutaneous and Visceral Leishmaniasis. J. Clin. Microbiol. 2018, 56. [CrossRef]

67. Verma, S.; Singh, R.; Sharma, V.; Bumb, R.A.; Negi, N.S.; Ramesh, V.; Salotra, P. Development of a rapid loop-mediated isothermal amplification assay for diagnosis and assessment of cure of Leishmania infection. BMC Infect. Dis. 2017, 17, 223. [CrossRef]

68. Badaró, R.; Benson, D.; Eulálio, M.C.; Freire, M.; Cunha, S.; Netto, E.M.; Pedral-Sampaio, D.; Madureira, C.; Burns, J.M.; Houghton, R.L.; et al. rK39: A cloned antigen of Leishmania chagasi that predicts active visceral leishmaniasis. J. Infect. Dis. 1996, 173, 758-761. [CrossRef] 
69. Braz, R.F.; Nascimento, E.T.; Martins, D.R.; Wilson, M.E.; Pearson, R.D.; Reed, S.G.; Jeronimo, S.M. The sensitivity and specificity of Leishmania chagasi recombinant K39 antigen in the diagnosis of American visceral leishmaniasis and in differentiating active from subclinical infection. Am. J. Trop. Med. Hyg. 2002, 67, 344-348. [CrossRef]

70. Maia, Z.; Lírio, M.; Mistro, S.; Mendes, C.M.; Mehta, S.R.; Badaro, R. Comparative study of rK39 Leishmania antigen for serodiagnosis of visceral leishmaniasis: Systematic review with meta-analysis. PLoS Negl. Trop. Dis. 2012, 6, e1484. [CrossRef]

71. Pedras, M.J.; de Gouvêa Viana, L.; de Oliveira, E.J.; Rabello, A. Comparative evaluation of direct agglutination test, rK39 and soluble antigen ELISA and IFAT for the diagnosis of visceral leishmaniasis. Trans. R. Soc. Trop. Med. Hyg. 2008, 102, 172-178. [CrossRef] [PubMed]

72. Singh, D.P.; Goyal, R.K.; Singh, R.K.; Sundar, S.; Mohapatra, T.M. In search of an ideal test for diagnosis and prognosis of kala-azar. J. Health Popul. Nutr. 2010, 28, 281-285. [CrossRef] [PubMed]

73. Zijlstra, E.E.; Daifalla, N.S.; Kager, P.A.; Khalil, E.A.; El-Hassan, A.M.; Reed, S.G.; Ghalib, H.W. rK39 enzyme-linked immunosorbent assay for diagnosis of Leishmania donovani infection. Clin. Diagn. Lab. Immunol. 1998, 5, 717-720. [CrossRef] [PubMed]

74. Carvalho, F.A.; Charest, H.; Tavares, C.A.; Matlashewski, G.; Valente, E.P.; Rabello, A.; Gazzinelli, R.T.; Fernandes, A.P. Diagnosis of American visceral leishmaniasis in humans and dogs using the recombinant Leishmania donovani A2 antigen. Diagn. Microbiol. Infect. Dis. 2002, 43, 289-295. [CrossRef]

75. Dhom-Lemos, L.; Viana, A.G.; Cunha, J.L.R.; Cardoso, M.S.; Mendes, T.A.O.; Pinheiro, G.R.G.; Siqueira, W.F.; Lobo, F.P.; Teles, L.F.; Bueno, L.L.; et al. Leishmania infantum recombinant kinesin degenerated derived repeat (rKDDR): A novel potential antigen for serodiagnosis of visceral leishmaniasis. PLoS ONE 2019, 14, e0211719. [CrossRef] [PubMed]

76. Ghedin, E.; Zhang, W.W.; Charest, H.; Sundar, S.; Kenney, R.T.; Matlashewski, G. Antibody response against a Leishmania donovani amastigote-stage-specific protein in patients with visceral leishmaniasis. Clin. Diagn. Lab. Immunol. 1997, 4, 530-535. [CrossRef] [PubMed]

77. Mohapatra, T.M.; Singh, D.P.; Sen, M.R.; Bharti, K.; Sundar, S. Compararative evaluation of rK9, rK26 and rK39 antigens in the serodiagnosis of Indian visceral leishmaniasis. J. Infect. Dev. Ctries. 2010, 4, 114-117. [CrossRef] [PubMed]

78. Takagi, H.; Islam, M.Z.; Itoh, M.; Islam, A.U.; Saifuddin Ekram, A.R.; Hussain, S.M.; Hashiguchi, Y.; Kimura, E. Short report: Production of recombinant kinesin-related protein of Leishmania donovani and its application in the serodiagnosis of visceral leishmaniasis. Am. J. Trop. Med. Hyg. 2007, 76, 902-905. [CrossRef]

79. Celeste, B.J.; Arroyo Sanchez, M.C.; Ramos-Sanchez, E.M.; Castro, L.G.M.; Lima Costa, F.A.; Goto, H. Recombinant Leishmania infantum heat shock protein 83 for the serodiagnosis of cutaneous, mucosal, and visceral leishmaniases. Am. J. Trop. Med. Hyg. 2014, 90, 860-865. [CrossRef]

80. Quijada, L.; Requena, J.M.; Soto, M.; Alonso, C. Analysis of the antigenic properties of the L. infantum Hsp70: Design of synthetic peptides for specific serodiagnosis of human leishmaniasis. Immunol. Lett. 1998, 63, 169-174. [CrossRef]

81. Kumar, D.; Kumar, S.; Chakravarty, J.; Sundar, S. A novel 12.6-kDa protein of Leishmania donovani for the diagnosis of Indian visceral leishmaniasis. Vector Borne Zoonotic Dis. 2011, 11, 1359-1364. [CrossRef] [PubMed]

82. Kumar, S.; Kumar, D.; Chakravarty, J.; Rai, M.; Sundar, S. Identification and characterization of a novel Leishmania donovani antigen for serodiagnosis of visceral leishmaniasis. Am. J. Trop. Med. Hyg. 2012, 86, 601-605. [CrossRef] [PubMed]

83. Kumar, S.; Kumar, D.; Chakravarty, J.; Sundar, S. Identification and Characterization of a Novel, 37-Kilodalton Leishmania donovani antigen for diagnosis of Indian visceral leishmaniasis. Clin. Vaccine Immunol. 2011, 18, 772-775. [CrossRef]

84. Duarte, M.C.; Pimenta, D.C.; Menezes-Souza, D.; Magalhães, R.D.; Diniz, J.L.; Costa, L.E.; Chávez-Fumagalli, M.A.; Lage, P.S.; Bartholomeu, D.C.; Alves, M.J.; et al. Proteins Selected in Leishmania (Viannia) braziliensis by an Immunoproteomic Approach with Potential Serodiagnosis Applications for Tegumentary Leishmaniasis. Clin. Vaccine Immunol. 2015, 22, 1187-1196. [CrossRef] 
85. Sato, C.M.; Sanchez, M.C.; Celeste, B.J.; Duthie, M.S.; Guderian, J.; Reed, S.G.; de Brito, M.E.; Campos, M.B.; de Souza Encarnação, H.V.; Guerra, J.; et al. Use of Recombinant Antigens for Sensitive Serodiagnosis of American Tegumentary Leishmaniasis Caused by Different Leishmania Species. J. Clin. Microbiol. 2017, 55, 495-503. [CrossRef] [PubMed]

86. Bangert, M.; Flores-Chávez, M.D.; Llanes-Acevedo, I.P.; Arcones, C.; Chicharro, C.; García, E.; Ortega, S.; Nieto, J.; Cruz, I. Validation of rK39 immunochromatographic test and direct agglutination test for the diagnosis of Mediterranean visceral leishmaniasis in Spain. PLoS Negl. Trop. Dis. 2018, 12, e0006277. [CrossRef]

87. Boelaert, M.; Rijal, S.; Regmi, S.; Singh, R.; Karki, B.; Jacquet, D.; Chappuis, F.; Campino, L.; Desjeux, P.; Le Ray, D.; et al. A comparative study of the effectiveness of diagnostic tests for visceral leishmaniasis. Am. J. Trop. Med. Hyg. 2004, 70, 72-77. [CrossRef] [PubMed]

88. Iqbal, J.; Hira, P.R.; Saroj, G.; Philip, R.; Al-Ali, F.; Madda, P.J.; Sher, A. Imported visceral leishmaniasis: Diagnostic dilemmas and comparative analysis of three assays. J. Clin. Microbiol. 2002, 40, 475-479. [CrossRef]

89. Barroso-Freitas, A.P.; Passos, S.R.; Mouta-Confort, E.; Madeira, M.F.; Schubach, A.O.; Santos, G.P.; Nascimento, L.D.; Marzochi, M.C.; Marzochi, K.B. Accuracy of an ELISA and indirect immunofluorescence for the laboratory diagnosis of American tegumentary leishmaniasis. Trans. R. Soc. Trop. Med. Hyg. 2009, 103, 383-389. [CrossRef]

90. de Assis, T.S.; Braga, A.S.; Pedras, M.J.; Oliveira, E.; Barral, A.; de Siqueira, I.C.; Costa, C.H.; Costa, D.L.; Holanda, T.A.; Soares, V.Y.; et al. Multi-centric prospective evaluation of rk39 rapid test and direct agglutination test for the diagnosis of visceral leishmaniasis in Brazil. Trans. R. Soc. Trop. Med. Hyg. 2011, 105, 81-85. [CrossRef]

91. Fakhar, M.; Asadi Kia, A.; Gohardehi, S.; Sharif, M.; Mohebali, M.; Akhoundi, B.; Pagheh, A.; Dadimoghadam, Y.; Cheraghali, F. Emergence of a new focus of visceral leishmaniasis due to Leishmania infantum in Golestan Province, north-eastern of Iran. J. Parasit. Dis. 2014, 38, 255-259. [CrossRef]

92. Cunningham, J.; Hasker, E.; Das, P.; El Safi, S.; Goto, H.; Mondal, D.; Mbuchi, M.; Mukhtar, M.; Rabello, A.; Rijal, S.; et al. A global comparative evaluation of commercial immunochromatographic rapid diagnostic tests for visceral leishmaniasis. Clin. Infect. Dis. 2012, 55, 1312-1319. [CrossRef]

93. Ejazi, S.A.; Ghosh, S.; Saha, S.; Choudhury, S.T.; Bhattacharyya, A.; Chatterjee, M.; Pandey, K.; Das, V.N.R.; Das, P.; Rahaman, M.; et al. A multicentric evaluation of dipstick test for serodiagnosis of visceral leishmaniasis in India, Nepal, Sri Lanka, Brazil, Ethiopia and Spain. Sci. Rep. 2019, 9, 9932. [CrossRef]

94. Saha, S.; Goswami, R.; Pramanik, N.; Guha, S.K.; Saha, B.; Rahman, M.; Mallick, S.; Modak, D.; Silva, F.O.; Mendonca, I.L.; et al. Easy test for visceral Leishmaniasis and post-Kala-azar Dermal Leishmaniasis. Emerg. Infect. Dis. 2011, 17, 1304-1306. [CrossRef]

95. Mary, C.; Lamouroux, D.; Dunan, S.; Quilici, M. Western blot analysis of antibodies to Leishmania infantum antigens: Potential of the 14-kD and 16-kD antigens for diagnosis and epidemiologic purposes. Am. J. Trop. Med. Hyg. 1992, 47, 764-771. [CrossRef] [PubMed]

96. Santos-Gomes, G.; Gomes-Pereira, S.; Campino, L.; Araújo, M.D.; Abranches, P. Performance of immunoblotting in diagnosis of visceral Leishmaniasis in human immunodeficiency virus-Leishmania sp.-coinfected patients. J. Clin. Microbiol. 2000, 38, 175-178. [PubMed]

97. Zeyrek, F.Y.; Korkmaz, M.; Ozbel, Y. Serodiagnosis of anthroponotic cutaneous leishmaniasis (ACL) caused by Leishmania tropica in Sanliurfa Province, Turkey, where ACL Is highly endemic. Clin. Vaccine Immunol. 2007, 14, 1409-1415. [CrossRef]

98. Heidari, S.; Gharechahi, J.; Mohebali, M.; Akhoundi, B.; Mirshahvaladi, S.; Azarian, B.; Hajjaran, H. Western Blot Analysis of Leishmania infantum Antigens in Sera of Patients with Visceral Leishmaniasis. Iran. J. Parasitol. 2019, 14, 10-19. [CrossRef] [PubMed]

99. Barrett, M.P.; Burchmore, R.J.; Stich, A.; Lazzari, J.O.; Frasch, A.C.; Cazzulo, J.J.; Krishna, S. The trypanosomiases. Lancet 2003, 362, 1469-1480. [CrossRef]

100. Sadlova, J.; Seblova, V.; Votypka, J.; Warburg, A.; Volf, P. Xenodiagnosis of Leishmania donovani in BALB/c mice using Phlebotomus orientalis: A new laboratory model. Parasites Vectors 2015, 8, 158. [CrossRef]

101. Lawyer, P.; Killick-Kendrick, M.; Rowland, T.; Rowton, E.; Volf, P. Laboratory colonization and mass rearing of phlebotomine sand flies (Diptera, Psychodidae). Parasite 2017, 24, 42. [CrossRef] [PubMed] 
102. Thakur, S.; Joshi, J.; Kaur, S. Leishmaniasis diagnosis: An update on the use of parasitological, immunological and molecular methods. J. Parasit. Dis. 2020, 44, 253-272. [CrossRef] [PubMed]

103. Seng, P.; Rolain, J.M.; Fournier, P.E.; La Scola, B.; Drancourt, M.; Raoult, D. MALDI-TOF-mass spectrometry applications in clinical microbiology. Future Microbiol. 2010, 5, 1733-1754. [CrossRef]

104. van Veen, S.Q.; Claas, E.C.; Kuijper, E.J. High-throughput identification of bacteria and yeast by matrix-assisted laser desorption ionization-time of flight mass spectrometry in conventional medical microbiology laboratories. J. Clin. Microbiol. 2010, 48, 900-907. [CrossRef] [PubMed]

105. Nasereddin, A.; Bensoussan-Hermano, E.; Schönian, G.; Baneth, G.; Jaffe, C.L. Molecular diagnosis of Old World cutaneous leishmaniasis and species identification by use of a reverse line blot hybridization assay. J. Clin. Microbiol. 2008, 46, 2848-2855. [CrossRef] [PubMed]

106. Galluzzi, L.; Ceccarelli, M.; Diotallevi, A.; Menotta, M.; Magnani, M. Real-time PCR applications for diagnosis of leishmaniasis. Parasites Vectors 2018, 11, 273. [CrossRef] [PubMed]

107. Moreira, O.C.; Yadon, Z.E.; Cupolillo, E. The applicability of real-time PCR in the diagnostic of cutaneous leishmaniasis and parasite quantification for clinical management: Current status and perspectives. Acta Trop. 2018, 184, 29-37. [CrossRef]

108. Mary, C.; Faraut, F.; Drogoul, M.P.; Xeridat, B.; Schleinitz, N.; Cuisenier, B.; Dumon, H. Reference values for Leishmania infantum parasitemia in different clinical presentations: Quantitative polymerase chain reaction for therapeutic monitoring and patient follow-up. Am. J. Trop. Med. Hyg. 2006, 75, 858-863. [CrossRef]

109. Silva Nunes Bezerra, G.; Barbosa Júnior, W.L.; Virgínia Batista Vieira, A.; Xavier, A.T.; Sebastião Da Costa Lima Júnior, M.; Maria Xavier, E.; Silva, E.D.D.; Cintra Leal, N.; Medeiros, Z.M. Loop-mediated isothermal amplification methods for diagnosis of visceral leishmaniasis (kala-azar) -A systematic review. Expert Rev. Mol. Diagn. 2020, 20, 455-465. [CrossRef]

110. Rosenstraus, M.; Wang, Z.; Chang, S.Y.; DeBonville, D.; Spadoro, J.P. An internal control for routine diagnostic PCR: Design, properties, and effect on clinical performance. J. Clin. Microbiol. 1998, 36, 191-197. [CrossRef]

111. Yan, S.; Lodes, M.J.; Fox, M.; Myler, P.J.; Stuart, K. Characterization of the Leishmania donovani ribosomal RNA promoter. Mol. Biochem. Parasitol. 1999, 103, 197-210. [CrossRef]

112. Schonian, G.; Nasereddin, A.; Dinse, N.; Schweynoch, C.; Schallig, H.D.; Presber, W.; Jaffe, C.L. PCR diagnosis and characterization of Leishmania in local and imported clinical samples. Diagn. Microbiol. Infect. Dis. 2003, 47, 349-358. [CrossRef]

113. Cupolillo, E.; Grimaldi Junior, G.; Momen, H.; Beverley, S.M. Intergenic region typing (IRT): A rapid molecular approach to the characterization and evolution of Leishmania. Mol. Biochem. Parasitol. 1995, 73, 145-155. [CrossRef]

114. Uliana, S.R.; Nelson, K.; Beverley, S.M.; Camargo, E.P.; Floeter-Winter, L.M. Discrimination amongst Leishmania by polymerase chain reaction and hybridization with small subunit ribosomal DNA derived oligonucleotides. J. Eukaryot. Microbiol. 1994, 41, 324-330. [CrossRef]

115. Garcia, L.; Kindt, A.; Bermudez, H.; Llanos-Cuentas, A.; De Doncker, S.; Arevalo, J.; Wilber Quispe Tintaya, K.; Dujardin, J.C. Culture-independent species typing of neotropical Leishmania for clinical validation of a PCR-based assay targeting heat shock protein 70 genes. J. Clin. Microbiol. 2004, 42, 2294-2297. [CrossRef]

116. Fraga, J.; Montalvo, A.M.; Maes, L.; Dujardin, J.C.; Van der Auwera, G. HindII and SduI digests of heat-shock protein 70 PCR for Leishmania typing. Diagn. Microbiol. Infect. Dis. 2013, 77, 245-247. [CrossRef]

117. Fraga, J.; Veland, N.; Montalvo, A.M.; Praet, N.; Boggild, A.K.; Valencia, B.M.; Arevalo, J.; Llanos-Cuentas, A.; Dujardin, J.C.; Van der Auwera, G. Accurate and rapid species typing from cutaneous and mucocutaneous leishmaniasis lesions of the New World. Diagn. Microbiol. Infect. Dis. 2012, 74, 142-150. [CrossRef]

118. Montalvo, A.M.; Fraga, J.; Maes, I.; Dujardin, J.C.; Van der Auwera, G. Three new sensitive and specific heat-shock protein 70 PCRs for global Leishmania species identification. Eur. J. Clin. Microbiol. Infect. Dis. 2012, 31, 1453-1461. [CrossRef]

119. Espada, C.R.; Ortiz, P.A.; Shaw, J.J.; Barral, A.M.P.; Costa, J.M.L.; Uliana, S.R.B.; Coelho, A.C. Identification of Leishmania (Viannia) species and clinical isolates of Leishmania (Leishmania) amazonensis from Brazil using PCR-RFLP of the heat-shock protein 70 gene reveals some unexpected observations. Diagn. Microbiol. Infect. Dis. 2018, 91, 312-318. [CrossRef]

120. Marfurt, J.; Nasereddin, A.; Niederwieser, I.; Jaffe, C.L.; Beck, H.P.; Felger, I. Identification and differentiation of Leishmania species in clinical samples by PCR amplification of the miniexon sequence and subsequent restriction fragment length polymorphism analysis. J. Clin. Microbiol. 2003, 41, 3147-3153. [CrossRef] 
121. Degrave, W.; Fernandes, O.; Campbell, D.; Bozza, M.; Lopes, U. Use of molecular probes and PCR for detection and typing of Leishmania-A mini-review. Memórias Inst. Oswaldo Cruz 1994, 89, 463-469. [CrossRef]

122. Rocha, M.N.; Margonari, C.; Presot, I.M.; Soares, R.P. Evaluation of 4 polymerase chain reaction protocols for cultured Leishmania spp. typing. Diagn. Microbiol. Infect. Dis. 2010, 68, 401-409. [CrossRef]

123. Marfurt, J.; Niederwieser, I.; Makia, N.D.; Beck, H.P.; Felger, I. Diagnostic genotyping of Old and New World Leishmania species by PCR-RFLP. Diagn. Microbiol. Infect. Dis. 2003, 46, 115-124. [CrossRef]

124. Roelfsema, J.H.; Nozari, N.; Herremans, T.; Kortbeek, L.M.; Pinelli, E. Evaluation and improvement of two PCR targets in molecular typing of clinical samples of Leishmania patients. Exp. Parasitol. 2011, 127, 36-41. [CrossRef]

125. Victoir, K.; Bañuls, A.L.; Arevalo, J.; Llanos-Cuentas, A.; Hamers, R.; Noël, S.; De Doncker, S.; Le Ray, D.; Tibayrenc, M.; Dujardin, J.C. The gp63 gene locus, a target for genetic characterization of Leishmania belonging to subgenus Viannia. Parasitology 1998, 117 Pt 1, 1-13. [CrossRef]

126. Laurent, T.; Van der Auwera, G.; Hide, M.; Mertens, P.; Quispe-Tintaya, W.; Deborggraeve, S.; De Doncker, S.; Leclipteux, T.; Bañuls, A.L.; Büscher, P.; et al. Identification of Old World Leishmania spp. by specific polymerase chain reaction amplification of cysteine proteinase B genes and rapid dipstick detection. Diagn. Microbiol. Infect. Dis. 2009, 63, 173-181. [CrossRef]

127. Garcia, A.L.; Kindt, A.; Quispe-Tintaya, K.W.; Bermudez, H.; Llanos, A.; Arevalo, J.; Bañuls, A.L.; De Doncker, S.; Le Ray, D.; Dujardin, J.C. American tegumentary leishmaniasis: Antigen-gene polymorphism, taxonomy and clinical pleomorphism. Infect. Genet. Evol. 2005, 5, 109-116. [CrossRef]

128. Jensen, R.E.; Englund, P.T. Network news: The replication of kinetoplast DNA. Annu. Rev. Microbiol. 2012, 66, 473-491. [CrossRef]

129. Aransay, A.M.; Scoulica, E.; Tselentis, Y. Detection and identification of Leishmania DNA within naturally infected sand flies by seminested PCR on minicircle kinetoplastic DNA. Appl. Environ. Microbiol. 2000, 66, 1933-1938. [CrossRef] [PubMed]

130. Mahboudi, F.; Abolhassani, M.; Tehrani, S.R.; Azimi, M.; Asmar, M. Differentiation of old and new world Leishmania species at complex and species levels by PCR. Scand. J. Infect. Dis. 2002, 34, 756-758. [CrossRef] [PubMed]

131. Sanger, F.; Nicklen, S.; Coulson, A.R. DNA sequencing with chain-terminating inhibitors. Proc. Natl. Acad. Sci. USA 1977, 74, 5463-5467. [CrossRef]

132. Uliana, S.R.; Affonso, M.H.; Camargo, E.P.; Floeter-Winter, L.M. Leishmania: Genus identification based on a specific sequence of the $18 \mathrm{~S}$ ribosomal RNA sequence. Exp. Parasitol. 1991, 72, 157-163. [CrossRef]

133. de Almeida, M.E.; Steurer, F.J.; Koru, O.; Herwaldt, B.L.; Pieniazek, N.J.; da Silva, A.J. Identification of Leishmania spp. by molecular amplification and DNA sequencing analysis of a fragment of rRNA internal transcribed spacer 2. J. Clin. Microbiol. 2011, 49, 3143-3149. [CrossRef]

134. Van der Auwera, G.; Ravel, C.; Verweij, J.J.; Bart, A.; Schonian, G.; Felger, I. Evaluation of four single-locus markers for Leishmania species discrimination by sequencing. J. Clin. Microbiol. 2014, 52, 1098-1104. [CrossRef]

135. Fraga, J.; Montalvo, A.M.; De Doncker, S.; Dujardin, J.C.; Van der Auwera, G. Phylogeny of Leishmania species based on the heat-shock protein 70 gene. Infect. Genet. Evol. 2010, 10, 238-245. [CrossRef]

136. da Silva, L.A.; de Sousa Cdos, S.; da Graca, G.C.; Porrozzi, R.; Cupolillo, E. Sequence analysis and PCR-RFLP profiling of the hsp70 gene as a valuable tool for identifying Leishmania species associated with human leishmaniasis in Brazil. Infect. Genet. Evol. 2010, 10, 77-83. [CrossRef]

137. Fernandes, O.; Murthy, V.K.; Kurath, U.; Degrave, W.M.; Campbell, D.A. Mini-exon gene variation in human pathogenic Leishmania species. Mol. Biochem. Parasitol. 1994, 66, 261-271. [CrossRef]

138. Zelazny, A.M.; Fedorko, D.P.; Li, L.; Neva, F.A.; Fischer, S.H. Evaluation of 7SL RNA gene sequences for the identification of Leishmania spp. Am. J. Trop. Med. Hyg. 2005, 72, 415-420. [CrossRef]

139. Stevenson, L.G.; Fedorko, D.P.; Zelazny, A.M. An enhanced method for the identification of Leishmania spp. using real-time polymerase chain reaction and sequence analysis of the 7SL RNA gene region. Diagn. Microbiol. Infect. Dis. 2010, 66, 432-435. [CrossRef]

140. Singh, N.; Curran, M.D.; Middleton, D.; Rastogi, A.K. Characterization of kinetoplast DNA minicircles of an Indian isolate of Leishmania donovani. Acta Trop. 1999, 73, 313-319. [CrossRef] 
141. Meehan, C.J.; Goig, G.A.; Kohl, T.A.; Verboven, L.; Dippenaar, A.; Ezewudo, M.; Farhat, M.R.; Guthrie, J.L.; Laukens, K.; Miotto, P.; et al. Whole genome sequencing of Mycobacterium tuberculosis: Current standards and open issues. Nat. Rev. Microbiol. 2019, 17, 533-545. [CrossRef]

142. Cantacessi, C.; Dantas-Torres, F.; Nolan, M.J.; Otranto, D. The past, present, and future of Leishmania genomics and transcriptomics. Trends Parasitol. 2015, 31, 100-108. [CrossRef]

143. Gerner-Smidt, P.; Besser, J.; Concepción-Acevedo, J.; Folster, J.P.; Huffman, J.; Joseph, L.A.; Kucerova, Z.; Nichols, M.C.; Schwensohn, C.A.; Tolar, B. Whole Genome Sequencing: Bridging One-Health Surveillance of Foodborne Diseases. Front. Public Health 2019, 7, 172. [CrossRef]

144. Williams, E.; Isles, N.S.; Seemann, T.; Kilpatrick, T.; Grigg, A.; Leroi, M.; Howden, B.P.; Kwong, J.C. Case Report: Confirmation by Metagenomic Sequencing of Visceral Leishmaniasis in an Immunosuppressed Returned Traveler. Am. J. Trop. Med. Hyg. 2020. [CrossRef]

145. Domagalska, M.A.; Dujardin, J.C. Next-Generation Molecular Surveillance of TriTryp Diseases. Trends Parasitol. 2020, 36, 356-367. [CrossRef]

146. Domagalska, M.A.; Imamura, H.; Sanders, M.; Van den Broeck, F.; Bhattarai, N.R.; Vanaerschot, M.; Maes, I.; D'Haenens, E.; Rai, K.; Rijal, S.; et al. Genomes of Leishmania parasites directly sequenced from patients with visceral leishmaniasis in the Indian subcontinent. PLoS Negl. Trop. Dis. 2019, 13, e0007900. [CrossRef]

147. Ghosh, P.; Hasnain, M.G.; Hossain, F.; Khan, M.A.A.; Chowdhury, R.; Faisal, K.; Mural, M.A.; Baker, J.; Nath, R.; Ghosh, D.; et al. Evaluation of Real-time PCR for Diagnosis of Post-Kala-azar Dermal Leishmaniasis in Endemic Foci of Bangladesh. Open Forum Infect. Dis. 2018, 5, ofy234. [CrossRef]

148. Gomes, C.M.; Cesetti, M.V.; de Paula, N.A.; Vernal, S.; Gupta, G.; Sampaio, R.N.; Roselino, A.M. Field Validation of SYBR Green- and TaqMan-Based Real-Time PCR Using Biopsy and Swab Samples to Diagnose American Tegumentary Leishmaniasis in an Area Where Leishmania (Viannia) braziliensis Is Endemic. J. Clin. Microbiol. 2017, 55, 526-534. [CrossRef]

149. Valencia, B.M.; Veland, N.; Alba, M.; Adaui, V.; Arevalo, J.; Low, D.E.; Llanos-Cuentas, A.; Boggild, A.K. Non-invasive cytology brush PCR for the diagnosis and causative species identification of American cutaneous leishmaniasis in Peru. PLoS ONE 2012, 7, e49738. [CrossRef]

150. Adams, E.R.; Gomez, M.A.; Scheske, L.; Rios, R.; Marquez, R.; Cossio, A.; Albertini, A.; Schallig, H.; Saravia, N.G. Sensitive diagnosis of cutaneous leishmaniasis by lesion swab sampling coupled to qPCR. Parasitology 2014, 141, 1891-1897. [CrossRef]

151. Molina, I.; Fisa, R.; Riera, C.; Falcó, V.; Elizalde, A.; Salvador, F.; Crespo, M.; Curran, A.; López-Chejade, P.; Tebar, S.; et al. Ultrasensitive real-time PCR for the clinical management of visceral leishmaniasis in HIV-Infected patients. Am. J. Trop. Med. Hyg. 2013, 89, 105-110. [CrossRef]

152. Disch, J.; Oliveira, M.C.; Orsini, M.; Rabello, A. Rapid clearance of circulating Leishmania kinetoplast DNA after treatment of visceral leishmaniasis. Acta Trop. 2004, 92, 279-283. [CrossRef]

153. Maurya, R.; Singh, R.K.; Kumar, B.; Salotra, P.; Rai, M.; Sundar, S. Evaluation of PCR for diagnosis of Indian kala-azar and assessment of cure. J. Clin. Microbiol. 2005, 43, 3038-3041. [CrossRef]

154. Jara, M.; Adaui, V.; Valencia, B.M.; Martinez, D.; Alba, M.; Castrillon, C.; Cruz, M.; Cruz, I.; Van der Auwera, G.; Llanos-Cuentas, A.; et al. Real-time PCR assay for detection and quantification of Leishmania (Viannia) organisms in skin and mucosal lesions: Exploratory study of parasite load and clinical parameters. J. Clin. Microbiol. 2013, 51, 1826-1833. [CrossRef]

155. Jara, M.; Valencia, B.M.; Adaui, V.; Alba, M.; Lau, R.; Arevalo, J.; Llanos-Cuentas, A.; Boggild, A.K. Quantitative Kinetoplast DNA Assessment during Treatment of Mucosal Leishmaniasis as a Potential Biomarker of Outcome: A Pilot Study. Am. J. Trop. Med. Hyg. 2016, 94, 107-113. [CrossRef]

156. Brito, M.E.; Andrade, M.S.; Mendonca, M.G.; Silva, C.J.; Almeida, E.L.; Lima, B.S.; Felix, S.M.; Abath, F.G.; da Graca, G.C.; Porrozzi, R.; et al. Species diversity of Leishmania (Viannia) parasites circulating in an endemic area for cutaneous leishmaniasis located in the Atlantic rainforest region of northeastern Brazil. Trop. Med. Int. Health 2009, 14, 1278-1286. [CrossRef]

157. Rosales-Chilama, M.; Gongora, R.E.; Valderrama, L.; Jojoa, J.; Alexander, N.; Rubiano, L.C.; Cossio, A.; Adams, E.R.; Saravia, N.G.; Gomez, M.A. Parasitological Confirmation and Analysis of Leishmania Diversity in Asymptomatic and Subclinical Infection following Resolution of Cutaneous Leishmaniasis. PLoS Negl. Trop. Dis. 2015, 9, e0004273. [CrossRef] [PubMed] 
158. Mirzaei, A.; Ahmadipour, F.; Cannet, A.; Marty, P.; Delaunay, P.; Perrin, P.; Dorkeld, F.; Sereno, D.; Akhoundi, M. Immunodetection and molecular determination of visceral and cutaneous Leishmania infection using patients' urine. Infect. Genet. Evol. 2018, 63, 257-268. [CrossRef]

159. Fisa, R.; Riera, C.; López-Chejade, P.; Molina, I.; Gállego, M.; Falcó, V.; Ribera, E.; Portús, M. Leishmania infantum DNA detection in urine from patients with visceral leishmaniasis and after treatment control. Am. J. Trop. Med. Hyg. 2008, 78, 741-744. [CrossRef]

160. Mori, Y.; Notomi, T. Loop-mediated isothermal amplification (LAMP): Expansion of its practical application as a tool to achieve universal health coverage. J. Infect. Chemother. 2020, 26, 13-17. [CrossRef]

161. Verma, S.; Avishek, K.; Sharma, V.; Negi, N.S.; Ramesh, V.; Salotra, P. Application of loop-mediated isothermal amplification assay for the sensitive and rapid diagnosis of visceral leishmaniasis and post-kala-azar dermal leishmaniasis. Diagn. Microbiol. Infect. Dis. 2013, 75, 390-395. [CrossRef]

162. Tripathi, P.; Singh, V.; Naik, S. Immune response to Leishmania: Paradox rather than paradigm. FEMS Immunol. Med. Microbiol. 2007, 51, 229-242. [CrossRef] [PubMed]

163. Ejazi, S.A.; Ali, N. Developments in diagnosis and treatment of visceral leishmaniasis during the last decade and future prospects. Expert Rev. Anti-Infect. Ther. 2013, 11, 79-98. [CrossRef]

164. Cota, G.F.; de Sousa, M.R.; Demarqui, F.N.; Rabello, A. The diagnostic accuracy of serologic and molecular methods for detecting visceral leishmaniasis in HIV infected patients: Meta-analysis. PLoS Negl. Trop. Dis. 2012, 6, e1665. [CrossRef] [PubMed]

165. De Brito, R.C.F.; Aguiar-Soares, R.D.O.; Cardoso, J.M.O.; Coura-Vital, W.; Roatt, B.M.; Reis, A.B. Recent advances and new strategies in Leishmaniasis diagnosis. Appl. Microbiol. Biotechnol. 2020, 104, 8105-8116. [CrossRef]

166. Cobo, F. Leishmaniasis. In Imported Infectious Diseases: The Impact in Development Countries, 1st ed.; Woodhead Publishing Elsevier: Cambridge, UK, 2014; p. 240.

167. Guimarães, M.C.; Celeste, B.J.; Franco, E.L. Diagnostic performance indices for immunofluorescent tests and enzyme immunoassays of leishmaniasis sera from northern and north-eastern Brazil. Bull. World Health Organ. 1990, 68, 39-43.

168. Brito, M.E.; Mendonça, M.G.; Gomes, Y.M.; Jardim, M.L.; Abath, F.G. Identification of potentially diagnostic Leishmania braziliensis antigens in human cutaneous leishmaniasis by immunoblot analysis. Clin. Diagn. Lab. Immunol. 2000, 7, 318-321. [CrossRef] [PubMed]

169. Kohanteb, J.; Ardehali, S. Cross-reaction of sera from patients with various infectious diseases with Leishmania infantum. Med. Princ. Pract. 2005, 14, 79-82. [CrossRef] [PubMed]

170. Souza, A.P.; Soto, M.; Costa, J.M.; Boaventura, V.S.; de Oliveira, C.I.; Cristal, J.R.; Barral-Netto, M.; Barral, A. Towards a more precise serological diagnosis of human tegumentary leishmaniasis using Leishmania recombinant proteins. PLoS ONE 2013, 8, e66110. [CrossRef] [PubMed]

171. Abass, E.; Kang, C.; Martinkovic, F.; Semião-Santos, S.J.; Sundar, S.; Walden, P.; Piarroux, R.; El Harith, A.; Lohoff, M.; Steinhoff, U. Heterogeneity of Leishmania donovani parasites complicates diagnosis of visceral leishmaniasis: Comparison of different serological tests in three endemic regions. PLoS ONE 2015, 10, e0116408. [CrossRef]

172. Ghosh, P.; Bhaskar, K.R.; Hossain, F.; Khan, M.A.; Vallur, A.C.; Duthie, M.S.; Hamano, S.; Salam, M.A.; Huda, M.M.; Khan, M.G.; et al. Evaluation of diagnostic performance of rK28 ELISA using urine for diagnosis of visceral leishmaniasis. Parasites Vectors 2016, 9, 383. [CrossRef] [PubMed]

173. Ejazi, S.A.; Bhattacharya, P.; Bakhteyar, M.A.; Mumtaz, A.A.; Pandey, K.; Das, V.N.; Das, P.; Rahaman, M.; Goswami, R.P.; Ali, N. Noninvasive Diagnosis of Visceral Leishmaniasis: Development and Evaluation of Two Urine-Based Immunoassays for Detection of Leishmania donovani Infection in India. PLoS Negl. Trop. Dis. 2016, 10, e0005035. [CrossRef]

174. Ostyn, B.; Gidwani, K.; Khanal, B.; Picado, A.; Chappuis, F.; Singh, S.P.; Rijal, S.; Sundar, S.; Boelaert, M. Incidence of symptomatic and asymptomatic Leishmania donovani infections in high-endemic foci in India and Nepal: A prospective study. PLoS Negl. Trop. Dis. 2011, 5, e1284. [CrossRef] [PubMed]

175. ter Horst, R.; Tefera, T.; Assefa, G.; Ebrahim, A.Z.; Davidson, R.N.; Ritmeijer, K. Field evaluation of rK39 test and direct agglutination test for diagnosis of visceral leishmaniasis in a population with high prevalence of human immunodeficiency virus in Ethiopia. Am. J. Trop. Med. Hyg. 2009, 80, 929-934. [CrossRef] 
176. Elmahallawy, E.K.; Sampedro Martinez, A.; Rodriguez-Granger, J.; Hoyos-Mallecot, Y.; Agil, A.; Navarro Mari, J.M.; Gutierrez Fernandez, J. Diagnosis of leishmaniasis. J. Infect. Dev. Ctries. 2014, 8, 961-972. [CrossRef]

177. Schoone, G.J.; Hailu, A.; Kroon, C.C.; Nieuwenhuys, J.L.; Schallig, H.D.; Oskam, L. A fast agglutination screening test (FAST) for the detection of anti-Leishmania antibodies. Trans. R. Soc. Trop. Med. Hyg. 2001, 95, 400-401. [CrossRef]

178. Patil, R.R.; Muliyil, J.P.; Nandy, A.; Addy, A.; Maji, A.K.; Chatterjee, P. Dynamics of the antibodies in cohorts of cured cases of visceral leishmaniasis: Its implication on the validity of serological test, value in prognosis and in post therapeutic assessment. Hum. Vaccines Immunother. 2012, 8, 725-730. [CrossRef]

179. Hailu, A. The use of direct agglutination test (DAT) in serological diagnosis of Ethiopian cutaneous leishmaniasis. Diagn. Microbiol. Infect. Dis. 2002, 42, 251-256. [CrossRef]

180. Silva, E.S.; Schoone, G.J.; Gontijo, C.M.; Brazil, R.P.; Pacheco, R.S.; Schallig, H.D. Application of direct agglutination test (DAT) and fast agglutination screening test (FAST) for sero-diagnosis of visceral leishmaniasis in endemic area of Minas Gerais, Brazil. Kinetoplastid Biol. Dis. 2005, 4, 4. [CrossRef]

181. Ghose, A.C.; Haldar, J.P.; Pal, S.C.; Mishra, B.P.; Mishra, K.K. Serological investigations on Indian kala-azar. Clin. Exp. Immunol. 1980, 40, 318-326.

182. Jamil, A.-m.; Mohamed Omer, F.; Abdalla, S.; El-Menshawy, N.; Al-Bin-Ali, A. Comparison of an indirect hemagglutination test and bone marrow aspiration for the diagnosis of visceral leishmaniasis in Aseer area, Saudi Arabia. Egypt. J. Haematol. 2012, 37, 88-90. [CrossRef]

183. Mendoza, J.; Rojas, A.; Plata, J.; Peis, J.; de la Rosa, M. Comparison of two indirect immunofluorescence techniques for the serodiagnosis of visceral leishmaniasis. Serodiagn. Immunother. Infect. Dis. 1990, 4, 341-343. [CrossRef]

184. Guimarães, M.C.; Celeste, B.J.; Franco, E.L.; Cucé, L.C.; Belda, W., Jr. Evaluation of serological diagnostic indices for mucocutaneous leishmaniasis: Immunofluorescence tests and enzyme-linked immunoassays for IgG, IgM and IgA antibodies. Bull. World Health Organ. 1989, 67, 643-648.

185. Burns, J.M., Jr.; Shreffler, W.G.; Benson, D.R.; Ghalib, H.W.; Badaro, R.; Reed, S.G. Molecular characterization of a kinesin-related antigen of Leishmania chagasi that detects specific antibody in African and American visceral leishmaniasis. Proc. Natl. Acad. Sci. USA 1993, 90, 775-779. [CrossRef]

186. Houghton, R.L.; Petrescu, M.; Benson, D.R.; Skeiky, Y.A.; Scalone, A.; Badaró, R.; Reed, S.G.; Gradoni, L. A cloned antigen (recombinant K39) of Leishmania chagasi diagnostic for visceral leishmaniasis in human immunodeficiency virus type 1 patients and a prognostic indicator for monitoring patients undergoing drug therapy. J. Infect. Dis. 1998, 177, 1339-1344. [CrossRef]

187. Carvalho, A.; Costa, L.E.; Salles, B.C.S.; Santos, T.T.O.; Ramos, F.F.; Lima, M.P.; Chávez-Fumagalli, M.A.; Silvestre, B.T.; Portela, Á.S.B.; Roatt, B.M.; et al. An ELISA immunoassay employing a conserved Leishmania hypothetical protein for the serodiagnosis of visceral and tegumentary leishmaniasis in dogs and humans. Cell Immunol. 2017, 318, 42-48. [CrossRef]

188. Ribeiro, P.A.F.; Dias, D.S.; Lage, D.P.; Costa, L.E.; Salles, B.C.S.; Steiner, B.T.; Ramos, F.F.; Lima, M.P.; Santos, T.T.O.; Chaves, A.T.; et al. A conserved Leishmania hypothetical protein evaluated for the serodiagnosis of canine and human visceral and tegumentary leishmaniasis, as well as a serological marker for the posttreatment patient follow-up. Diagn. Microbiol. Infect. Dis. 2018, 92, 196-203. [CrossRef]

189. Lindoso, J.A.; Barbosa, R.N.; Posada-Vergara, M.P.; Duarte, M.I.; Oyafuso, L.K.; Amato, V.S.; Goto, H. Unusual manifestations of tegumentary leishmaniasis in AIDS patients from the New World. Br. J. Dermatol. 2009, 160, 311-318. [CrossRef]

190. Amorim, A.G.; Carrington, M.; Miles, M.A.; Barker, D.C.; de Almeida, M.L. Identification of the C-terminal region of $70 \mathrm{kDa}$ heat shock protein from Leishmania (Viannia) braziliensis as a target for the humoral immune response. Cell Stress Chaperones 1996, 1, 177-187. [CrossRef]

191. Rey-Ladino, J.A.; Joshi, P.B.; Singh, B.; Gupta, R.; Reiner, N.E. Leishmania major: Molecular cloning, sequencing, and expression of the heat shock protein 60 gene reveals unique carboxy terminal peptide sequences. Exp. Parasitol. 1997, 85, 249-263. [CrossRef]

192. Menezes-Souza, D.; Mendes, T.A.; Gomes Mde, S.; Reis-Cunha, J.L.; Nagem, R.A.; Carneiro, C.M.; Coelho, E.A.; Galvão, L.M.; Fujiwara, R.T.; Bartholomeu, D.C. Epitope mapping of the HSP83.1 protein of Leishmania braziliensis discloses novel targets for immunodiagnosis of tegumentary and visceral clinical forms of leishmaniasis. Clin. Vaccine Immunol. 2014, 21, 949-959. [CrossRef] 
193. Coelho, E.A.; Costa, L.E.; Lage, D.P.; Martins, V.T.; Garde, E.; de Jesus Pereira, N.C.; Lopes, E.G.; Borges, L.F.; Duarte, M.C.; Menezes-Souza, D.; et al. Evaluation of two recombinant Leishmania proteins identified by an immunoproteomic approach as tools for the serodiagnosis of canine visceral and human tegumentary leishmaniasis. Vet. Parasitol. 2016, 215, 63-71. [CrossRef]

194. Salles, B.C.S.; Dias, D.S.; Steiner, B.T.; Lage, D.P.; Ramos, F.F.; Ribeiro, P.A.F.; Santos, T.T.O.; Lima, M.P.; Costa, L.E.; Chaves, A.T.; et al. Potential application of small myristoylated protein-3 evaluated as recombinant antigen and a synthetic peptide containing its linear B-cell epitope for the serodiagnosis of canine visceral and human tegumentary leishmaniasis. Immunobiology 2019, 224, 163-171. [CrossRef] [PubMed]

195. Lage, D.P.; Machado, A.S.; Ramos, F.F.; Silveira, P.C.; Dias, D.S.; Ribeiro, P.A.F.; Tavares, G.S.V.; Costa, L.E.; Santos, T.T.O.; Steiner, B.T.; et al. A biomarker for tegumentary and visceral leishmaniasis based on a recombinant Leishmania hypothetical protein. Immunobiology 2019, 224, 477-484. [CrossRef]

196. Freire, M.L.; Assis, T.S.M.; Avelar, D.M.; Rabello, A.; Cota, G. Evaluation of a new brand of immunochromatographic test for visceral leishmaniasis in Brazil made available from 2018. Rev. Inst. Med. Trop. Sao Paulo 2018, 60, e49. [CrossRef]

197. Anfossi, L.; Di Nardo, F.; Profiti, M.; Nogarol, C.; Cavalera, S.; Baggiani, C.; Giovannoli, C.; Spano, G.; Ferroglio, E.; Mignone, W.; et al. A versatile and sensitive lateral flow immunoassay for the rapid diagnosis of visceral leishmaniasis. Anal. Bioanal. Chem. 2018, 410, 4123-4134. [CrossRef]

198. Pattabhi, S.; Whittle, J.; Mohamath, R.; El-Safi, S.; Moulton, G.G.; Guderian, J.A.; Colombara, D.; Abdoon, A.O.; Mukhtar, M.M.; Mondal, D.; et al. Design, development and evaluation of rK28-based point-of-care tests for improving rapid diagnosis of visceral leishmaniasis. PLoS Negl. Trop. Dis. 2010, 4. [CrossRef] [PubMed]

199. Vaish, M.; Bhatia, A.; Reed, S.G.; Chakravarty, J.; Sundar, S. Evaluation of rK28 antigen for serodiagnosis of visceral Leishmaniasis in India. Clin. Microbiol. Infect. 2012, 18, 81-85. [CrossRef]

200. Karimi Kakh, M.; Golchin, M.; Kazemi Arababadi, M.; Daneshvar, H. Application of the Leishmania infantum 21-kDa recombinant protein for the development of an immunochromatographic test. Parasite Immunol. 2020, e12770. [CrossRef] [PubMed]

201. Ejazi, S.A.; Ghosh, S.; Bhattacharyya, A.; Kamran, M.; Das, S.; Bhowmick, S.; Rahaman, M.; Goswami, R.P.; Ali, N. Investigation of the antigenicity and protective efficacy of Leishmania promastigote membrane antigens in search of potential diagnostic and vaccine candidates against visceral leishmaniasis. Parasites Vectors 2020, 13, 272. [CrossRef] [PubMed]

202. Ejazi, S.A.; Bhattacharyya, A.; Choudhury, S.T.; Ghosh, S.; Sabur, A.; Pandey, K.; Das, V.N.R.; Das, P.; Rahaman, M.; Goswami, R.P.; et al. Immunoproteomic Identification and Characterization of Leishmania Membrane Proteins as Non-Invasive Diagnostic Candidates for Clinical Visceral Leishmaniasis. Sci. Rep. 2018, 8, 12110. [CrossRef] [PubMed]

203. Bhowmick, S.; Ali, N. Identification of novel Leishmania donovani antigens that help define correlates of vaccine-mediated protection in visceral leishmaniasis. PLoS ONE 2009, 4, e5820. [CrossRef] [PubMed]

204. Singh, M.K.; Jamal, F.; Dubey, A.K.; Shivam, P.; Kumari, S.; Pushpanjali; Bordoloi, C.; Narayan, S.; Das, V.N.R.; Pandey, K.; et al. Visceral leishmaniasis: A novel nuclear envelope protein 'nucleoporins-93 (NUP-93)' from Leishmania donovani prompts macrophage signaling for T-cell activation towards host protective immune response. Cytokine 2019, 113, 200-215. [CrossRef] [PubMed]

205. Humbert, M.V.; Costa, L.E.; Katis, I.; Fonseca Ramos, F.; Sanchéz Machado, A.; Sones, C.; Ferraz Coelho, E.A.; Christodoulides, M. A rapid diagnostic test for human Visceral Leishmaniasis using novel Leishmania antigens in a Laser Direct-Write Lateral Flow Device. Emerg. Microbes Infect. 2019, 8, 1178-1185. [CrossRef] [PubMed]

206. Boelaert, M.; Verdonck, K.; Menten, J.; Sunyoto, T.; van Griensven, J.; Chappuis, F.; Rijal, S. Rapid tests for the diagnosis of visceral leishmaniasis in patients with suspected disease. Cochrane Database Syst. Rev. 2014, 2014, Cd009135. [CrossRef]

207. Sundar, S.; Singh, O.P. Molecular Diagnosis of Visceral Leishmaniasis. Mol. Diagn. Ther. 2018, 22, 443-457. [CrossRef]

208. van Griensven, J.; van Henten, S.; Mengesha, B.; Kassa, M.; Adem, E.; Endris Seid, M.; Abdellati, S.; Asefa, W.; Simegn, T.; Debasu, D.; et al. Longitudinal evaluation of asymptomatic Leishmania infection in HIV-infected individuals in North-West Ethiopia: A pilot study. PLoS Negl. Trop. Dis. 2019, 13, e0007765. [CrossRef]

209. Bhattacharyya, T.; Boelaert, M.; Miles, M.A. Comparison of visceral leishmaniasis diagnostic antigens in African and Asian Leishmania donovani reveals extensive diversity and region-specific polymorphisms. PLoS Negl. Trop. Dis. 2013, 7, e2057. [CrossRef] 
210. Sanchez, M.C.A.; Celeste, B.J.; Lindoso, J.A.L.; Fujimori, M.; de Almeida, R.P.; Fortaleza, C.; Druzian, A.F.; Lemos, A.P.F.; de Melo, V.C.A.; Miranda Paniago, A.M.; et al. Performance of rK39-based immunochromatographic rapid diagnostic test for serodiagnosis of visceral leishmaniasis using whole blood, serum and oral fluid. PLOS ONE 2020, 15, e0230610. [CrossRef]

211. Riera, C.; Fisa, R.; Lopez, P.; Ribera, E.; Carrió, J.; Falcó, V.; Molina, I.; Gállego, M.; Portús, M. Evaluation of a latex agglutination test (KAtex) for detection of Leishmania antigen in urine of patients with HIV-Leishmania coinfection: Value in diagnosis and post-treatment follow-up. Eur. J. Clin. Microbiol. Infect. Dis. 2004, 23, 899-904. [CrossRef]

212. Vilaplana, C.; Blanco, S.; Domínguez, J.; Giménez, M.; Ausina, V.; Tural, C.; Muñoz, C. Noninvasive method for diagnosis of visceral leishmaniasis by a latex agglutination test for detection of antigens in urine samples. J. Clin. Microbiol. 2004, 42, 1853-1854. [CrossRef] [PubMed]

213. Barbosa Júnior, W.L.; Ramos de Araújo, P.S.; Dias de Andrade, L.; Aguiar Dos Santos, A.M.; Lopes da Silva, M.A.; Dantas-Torres, F.; Medeiros, Z. Rapid Tests and the Diagnosis of Visceral Leishmaniasis and Human Immunodeficiency Virus/Acquired Immunodeficiency Syndrome Coinfection. Am. J. Trop. Med. Hyg. 2015, 93, 967-969. [CrossRef]

214. Vogt, F.; Mengesha, B.; Asmamaw, H.; Mekonnen, T.; Fikre, H.; Takele, Y.; Adem, E.; Mohammed, R.; Ritmeijer, K.; Adriaensen, W.; et al. Antigen Detection in Urine for Noninvasive Diagnosis and Treatment Monitoring of Visceral Leishmaniasis in Human Immunodeficiency Virus Coinfected Patients: An Exploratory Analysis from Ethiopia. Am. J. Trop. Med. Hyg. 2018, 99, 957-966. [CrossRef] [PubMed]

215. Abeijon, C.; Kashino, S.S.; Silva, F.O.; Costa, D.L.; Fujiwara, R.T.; Costa, C.H.; Campos-Neto, A. Identification and diagnostic utility of Leishmania infantum proteins found in urine samples from patients with visceral leishmaniasis. Clin. Vaccine Immunol. 2012, 19, 935-943. [CrossRef] [PubMed]

216. Abeijon, C.; Campos-Neto, A. Potential non-invasive urine-based antigen (protein) detection assay to diagnose active visceral leishmaniasis. PLoS Negl. Trop. Dis. 2013, 7, e2161. [CrossRef] [PubMed]

217. Abeijon, C.; Alves, F.; Monnerat, S.; Mbui, J.; Viana, A.G.; Almeida, R.M.; Bueno, L.L.; Fujiwara, R.T.; Campos-Neto, A. Urine-based antigen detection assay for diagnosis of visceral leishmaniasis using monoclonal antibodies specific for six protein biomarkers of Leishmania infantum/Leishmania donovani. PLoS Negl. Trop. Dis. 2020, 14, e0008246. [CrossRef]

218. Marlais, T.; Bhattacharyya, T.; Pearson, C.; Gardner, B.L.; Marhoon, S.; Airs, S.; Hayes, K.; Falconar, A.K.; Singh, O.P.; Reed, S.G.; et al. Isolation and characterisation of Leishmania donovani protein antigens from urine of visceral leishmaniasis patients. PLOS ONE 2020, 15, e0238840. [CrossRef]

Publisher's Note: MDPI stays neutral with regard to jurisdictional claims in published maps and institutional affiliations.

(C) 2020 by the authors. Licensee MDPI, Basel, Switzerland. This article is an open access article distributed under the terms and conditions of the Creative Commons Attribution (CC BY) license (http://creativecommons.org/licenses/by/4.0/). 